\title{
Career and Wage Dynamics \\ Evidence from Linked Employer-Employee Data
}

Antti Kauhanen ${ }^{*}$ - Sami Napari ${ }^{* *}$

* ETLA - Elinkeinoelämän Tutkimuslaitos, antti.kauhanen@etla.fi

* ETLA - Elinkeinoelämän Tutkimuslaitos, sami.napari@etla.fi 
We thank Juha-Pekka Jokinen for excellent research assistance. Funding from the Finnish Work Environment Fund is gratefully acknowledged.

ISSN 0781-6847 


\section{Contents}

$\begin{array}{ll}\text { Abstract } & 2\end{array}$

1 Introduction $\quad 3$

$2 \quad$ Theoretical background $\quad 4$

3 Data $r$

$\begin{array}{lll}3.1 & \text { The EK data } & 7\end{array}$

3.2 The Hierarchy $\quad 8$

3.3 Some descriptive results 9

4 Ports of entry and exit $\quad 12$

$\begin{array}{llr}5 & \text { Careers after entry } & 13\end{array}$

$\begin{array}{lll}5.1 & \text { Fast track promotions and exits } & 15\end{array}$

5.2 Promotions, exits and position in wage hierarchy 16

$\begin{array}{lll}5.3 & \text { Regression model for promotion } & 18\end{array}$

$\begin{array}{llr}6 & \text { Careers and wages } & 20\end{array}$

$\begin{array}{llr}7 & \text { Conclusions } & 25\end{array}$

$\begin{array}{ll}\text { References } & 27\end{array}$ 


\section{Tiivistelmä}

Tutkimuksessa tarkastellaan sekä yritysten sisäistä että yritysten välistä ura- ja palkkadynamiikkaa hyödyntämällä laajaa yhdistettyä työnantaja-työntekijä paneeliaineistoa. Käytettävä aineisto kattaa 26 vuoden ajanjakson ja se mahdollistaa kuusitasoisen vaativuustasohierarkian laatimisen yli 5000 yritykselle. Tutkimuksessa toistetaan monia Bakerin, Gibbsin ja Holmströmin (Quarterly Journal of Economics, 1994) tekemiä tarkasteluja, mutta samalla myös laajennetaan heidän analyysiaan ura- ja palkkadynamiikasta. Tutkimuksen tulokset antavat tukea monille heidän yhtä yritystä koskeville havainnoille. Urat yrityksissä ovat tärkeitä, mutta yrityksen sisäisten työmarkkinoiden teoria ei saa kuitenkaan varauksetonta tukea. Viimeaikaiset teoriat ura- ja palkkadynamiikasta pystyvät sen sijaan hyvin selittämään tutkimuksen empiirisiä havaintoja.

Asiasanat: Työurat, yritysten sisäiset työmarkkinat, ylennykset, liikkuvuus, palkkakasvu, sukupuolten väliset palkkaerot

\section{Abstract}

We study career and wage dynamics within and between firms using a large linked employer-employee panel dataset spanning 26 years. We construct six-level hierarchies for more than 5,000 firms. We replicate most of the analyses from Baker, Gibbs and Holmström (Quarterly Journal of Economics, 1994) and make some extensions. Many of our results corroborate their findings. Careers within firms are important, but the strong version of the theory of internal labor markets does not fit the data. Recent theories of career and wage dynamics explain our findings well.

Key words: Internal labor markets, employer changes, promotions, wage growth, human capital

JEL: M51, M12, J62, L22 


\section{Introduction}

During the last three decades, the fields of personnel economics and organizational economics have started to develop and test models of internal workings of firms. In this respect, they have moved beyond the traditional treatment of firms as "black boxes." A particular area that has received a lot of attention is internal labor markets, which refer to a set of practices through which firms restrict entry to certain positions, and thereafter, careers progress on a more or less specified path. The theory of internal labor markets also implies that wages are strongly tied to jobs and not to the characteristics of the jobholder.

Economic studies of careers in organizations were spurred by the seminal contribution of Baker et al. (1994). They studied the personnel records of a single US firm for a period of 20 years, focusing on the hierarchical structure of the firm, career and wage dynamics, and the role of hierarchical levels as determinants of pay. They found that the allocation of labor in the firm resembles an internal labor market in some respects, and that human capital, both general and firm-specific, and learning about employee ability are important for career dynamics.

These findings led to more elaborate theories of promotion and wage dynamics (e.g. Gibbons and Waldman 1999, Gibbons and Waldman 2006). One reason for the significant impact of the single-firm study by Baker et al. (1994) on theoretical work was its broad approach to careers in organizations. Indeed, Waldman (2007) argues that studies that consider many related phenomena of careers are especially helpful for theory development, given that a theory of careers in organizations should ideally describe many, if not all, empirical findings. Baker and Holmström (1995), on the other hand, have cautioned against using results from a single case study as a guide to theoretical research.

Yet, many of the empirical findings by Baker et al. (1994) have received support from other case studies, including Seltzer and Merrett (2000), Treble et al. (2001) and Dohmen et al. (2004), which use data from different institutional environments, time periods and industries. Nevertheless, there are also some important differences in the results between these studies, leaving open the question of which of the results hold true across various settings and which are particular to the specific case studies. Lazear and Oyer (2004) contribute to the literature by going beyond case study research and studying entry into and exit from firms using a large Swedish dataset. They conclude that external labor markets play an important role in Sweden, although internal promotion is important.

An additional aspect of career dynamics in firms that has recently received attention in the theoretical literature is employee turnover. The analysis of employee turnover has a long tradition in labor economics. Many theoretical studies, for instance, use search and matching models to analyze employer changes (e.g. Jovanovic 1979a, Jovanovic 1979b, Sicherman and Galor 1990, Neal 1999). Empirical studies have focused, inter alia, on occupational mobility and employer changes and on the wage effects of these career moves (e.g. Topel and Ward 1992, Farber 1994, Booth et al. 1999, Parrado et al. 2007). However, it is only recently that these ideas have been incorporated into models of careers in firms (e.g. Ghosh 2007). Waldman (2007) argues that career progression is closely related to voluntary and involuntary turnover decisions and calls for empirical studies to inform theoretical models on the connection of wage and promotion dynamics within a firm and the turnover decision. 
We study careers using a large linked employer-employee dataset including over 5,000 firms and more than 3.5 million observations on white-collar employees in the Finnish manufacturing sector over the period of 1981-2006. A novel feature of our dataset is that it allows us to rank jobs into hierarchies that are identical across firms. Our paper thus adds to the literature by shedding light on the question of how well the observations of the workings of the internal labor markets made in studies focusing on a single firm generalize to a larger set of firms. This also allows us to assess the existing theories in light of results that are not particular to a given firm. We also extend the earlier analysis of career and wage dynamics to cover firm changes as well. Most of the previous studies have either focused on internal labor markets or mobility between firms, and there are only a few papers analyzing promotions in tandem with employer changes (da Silva and van der Klaauw 2005 is an exception). ${ }^{1}$ Equipped with a measure of hierarchical levels that is comparable across firms, we are able to provide a broader description of careers than many of the earlier studies on the topic.

We focus on three main sets of issues. First, to provide information on how well the findings of the case studies regarding the workings of internal labor markets generalize to a larger set of firms, we replicate many of the analyses from Baker, Gibbs and Holmstrom (1994). These include the following questions: Is there evidence of ports of entry and exit? Are there fasttracks within firms? Do external hires experience different career development within firms than do incumbents? Second, with our unique data, we can also examine employer changes. Examples of questions investigated in this part are the following: How typical are employer changes? Are employer changes often associated with promotions? What factors contribute to promotions with employer changes? Finally, although promotions and employer changes are important parts of the career process, wages matter as well. Therefore, we also analyze wages and the wage gains of different career events. Here, we focus, among other things, on the following issues: How stable are wage differences across hierarchical levels and over business cycles? Are wages convex with respect to the hierarchical level? Are hierarchical levels important determinants of wages? Are there significant wage premiums on promotions?

The structure of the paper is as follows. In Section 2, we discuss the theoretical research on careers. Section 3 describes the data. In Section 4, we analyze the entry into and the exit from the hierarchical levels to examine whether firms restrict movements between internal and external labor markets to certain hierarchical levels, as outlined by Baker et al. (1994). Section 5 focuses on subsequent career development. Section 6 completes our investigation of careers by considering wage determination within firms, and the wage effects of different career moves. Finally, Section 7 summarizes the main findings of the paper.

\section{Theoretical background}

Despite the notable theoretical advances in the analysis of careers during the last two decades, there is still a lack of models that account for all of the empirical regularities of careers within a single framework. Therefore, instead of presenting in detail any particular model of careers,

\footnotetext{
Papers investigating internal labor markets were discussed above. Booth et al. (1999), Farber (1994), Munasinghe and Sigman (2004), Topel and Ward (1992) are examples of studies analyzing employer changes. Booth and Francesconi (2000), le Grand and Tåhlin (2002), and Pavlopoulos et al. (2007) are, on the other hand, examples of the few studies that have distinguished between intra-firm and inter-firm mobility.
} 
this section discusses several theories that help to understand the different aspects of careers investigated in this paper.

We start exploring careers by examining the ports of entry and exit. As discussed, for example, in Baker et al. (1994) and Lazear and Oyer (2004), one of the key elements of internal labor markets is the existence of jobs where most hiring (ports-of-entry) and separation (ports-ofexit) takes place. By restricting labor movements in and out of the firm to certain jobs, portsof-entry and ports-of-exit jobs provide insulation to internal labor markets from the competitive market forces. There are several reasons for the existence of ports of entry and exit jobs. One is the various administrative rules used by firms to restrict employees' mobility between jobs. Additionally, firm-specific human capital provides a plausible explanation for ports-ofentry (e.g. Becker 1962). Jobs higher in the hierarchy may require more firm-specific skills than jobs lower in the hierarchical ranks, in which case workers are hired into less demanding jobs (ports-of-entry) and climb up the hierarchical ladder after spending sufficient time in the firm to accumulate necessary firm-specific knowledge. If firm-specific human capital plays an important role in career development within firms, then outside recruits should have more general human capital to compete with incumbents (Baker et al. 1994). Yet another reason that might give rise to ports-of-entry is related to incentives. Lazear and Rosen (1981) and Rosen (1986) present a tournament model of internal labor markets, in which wages are attached to jobs rather than to worker characteristics. In this framework, a worker is promoted if he performs better than his co-workers at the same hierarchical level. Otherwise, he remains at his current level. Because not all workers receive promotion, the possibility of receiving one serves as an incentive device. The tournament model thus suggests that jobs at the top of the hierarchy are filled with workers who enter the jobs through internal promotions, whereas new outside recruits are hired into less demanding jobs from which the 'tournament' begins.

In Section 5, we turn to career dynamics after entry into the level. Gibbons and Waldman (1999) develop a model that captures many of the findings in Baker et al. (1994) and other studies on career and wage dynamics. Their model combines worker assignment, human capital acquisition, and learning. Jobs are ranked by the importance of ability, and it is efficient to assign more able workers to more demanding jobs. While performing their jobs, employees acquire general human capital. There is uncertainty about an employee's ability, but it is learned symmetrically over time from realization of production by all firms. In their $2006 \mathrm{pa}$ per, Gibbons and Waldman add schooling to this framework. Firms and workers make spot contracts, and workers are paid their expected productivity in advance of production. The productivity of an individual in a given job depends on on-the-job human capital, the level schooling, and random shocks. On-the-job human capital is a function of ability, schooling, and labor market experience. The initial assignment is determined by human capital acquired before entering the labor market. Subsequent career progression is, on the other hand, determined by on-the-job human capital and learning. Expectations of on-the-job human capital can change due to accumulation of work experience or due to updating of beliefs about ability. For example, promotions take place when expected effective ability (a function of ability, schooling, work experience, and prior productivity shocks) exceeds a given threshold. Demotions may also take place if the expectation of ability is revised downwards. This simple model can explain, for instance, why wages and education predict future promotion, why there are promotion fast-tracks, why large wage increases are attached to promotions, why wages are attached to jobs, and why wage distributions overlap across hierarchical levels. 
Bernhardt (1995) also develops a model that is able to account for many of the empirical findings of careers. A starting point in Bernhardt's analysis is the paper by Waldman (1984), in which promotions serve as signals of an employee's value, that is, learning about ability is asymmetric. Bernhardt extends Waldman's model, inter alia, by allowing a richer skill development process and considering more than two time periods. Similar to Waldman, in Bernhardt's model, the promotion process is also inefficient. Because promotion reveals information on a worker's ability, employers have incentives not to promote individuals as quickly as is socially optimal, but rather only when the productivity gains resulting from placing a highability worker upper in the hierarchy outweigh the value of the employer's private information.

The models presented above base promotion decisions on absolute performance: promotion takes place when expected productivity exceeds some standard. However, promotions can also be based on relative evaluation, as in tournament models of promotion (e.g. Lazear and Rosen 1981). Indeed, there is evidence that absolute performance is not all that matters for promotion but rather that relative performance also plays a role (DeVaro 2006).

Thus far, we have discussed models that examine careers within firms. However, many studies show that employer changes also play an important role in individuals' careers (e.g. Topel and Ward 1992). Therefore, the models of career dynamics should ideally simultaneously account for both within-firm mobility and employer changes. The number of theoretical studies along these lines is still scarce, but Ghosh (2007) provides one promising example of a paper that attempts to combine internal labor market literature and research on turnover behavior. Ghosh builds on Gibbons and Waldman (1999) and presents a multi-period model with a hierarchical firm structure where workers are assumed to accumulate both specific and general human capital. Furthermore, Ghosh assumes that workers experience disutility from working in a firm, the amount of which workers only learn gradually over time. The accumulation of firm-specific human capital decreases the likelihood of employer changes, while a high realized value of disutility increases turnover. Ghosh's model is able to account for some of the empirical findings concerning the characteristics of internal labor markets, and it also provides predictions about mobility between employers. For example, Ghosh's model predicts that the probability of employer changes decreases with labor market experience, a result that derives from the accumulation of firm-specific human capital.

We end our empirical examination of careers by investigating wages in Section 6. A central feature of internal labor markets is that wages are attached to jobs. Therefore, one of the issues analyzed in Section 6 is the relative importance of individual characteristics vs. job titles as determinants of wages and the contribution of different career tracks for wage growth. Furthermore, we also investigate wage structures within firms. To be more precise, we examine whether wages are convex with respect to hierarchical level. There are several models that predict increasing wage differences between consecutive hierarchical levels as one moves up the hierarchy. The tournament model by Rosen (1986) provides one example. Under the assumption that the effort level remains constant across the rounds of the tournament, Rosen shows that the wage increase resulting from winning the last round is higher compared to the wage gain resulting from winning earlier rounds. In terms of wage growth associated with career moves, much of the literature on career dynamics has focused on analyzing wage changes with promotions. Although these models typically predict wage increases with promotion, the reasons for wage premia differ between models. For example, in Bernhardt (1995), wages in- 
crease with promotion both because promotion reveals information about the worker's ability and because job assignment is more efficient due to promotion. In Lazear and Rosen's (1981) tournament model, on the other hand, wages increase with promotion because it provides incentives for workers to exert effort.

\section{Data}

\subsection{The EK data}

This paper uses a large linked employee-employer dataset from 1981 to 2006 . The data come from the records of the Confederation of Finnish Industries (EK), which is the central organization of employer associations in Finland. Although EK has member firms from many industries, manufacturing has traditionally been the most important sector represented in the data. The firms affiliated with EK represent over two-thirds of the Finnish GDP and over 90\% of exports. Of total employment in Finland, the member firms account for approximately $33 \%$. Hence, the data cover a significant share of the Finnish economy as a whole.

EK collects the data by sending annual surveys to its member firms. One of the main purposes of the data is to provide information to the central wage negotiations. Because it is mandatory for the member firms to respond to the survey, the non-response bias is practically nonexistent. The data are based on the administrative records of the member firms, which guarantees that all information is accurate and of very high quality. The EK dataset suits our research purposes well. First, it allows us to follow individuals' careers over a long period of time, up to 25 years. Second, the data enable us to distinguish between many different types of career moves. We can, for example, separate promotions from demotions and within-firm mobility from employer changes. Yet another advantage of our dataset is that it is exceptionally rich. It includes a large set of both employee and firm characteristics and, rather uniquely, some important information on co-workers as well. A more detailed description of the variables used in the paper is given in Section 5.

Although the data contain information on both white-collar and blue-collar workers, we restrict the analysis to full-time, white-collar employees. ${ }^{2}$ This is mainly because of the complexities in the occupation classification system in the blue-collar data. Unlike white-collar employees, it is not possible to allocate blue-collar workers systematically to different hierarchical positions based on the job they hold. Furthermore, restricting the sample to fulltime workers is of little importance in practice because the share of part-time workers is negligible among white-collar workers, roughly $2 \%$ in 2006 . Furthermore, there are only small gender differences in this respect. The data include over 3,500,000 observations in total, of which $36.7 \%$ are women. ${ }^{3}$ The number of individuals is 467,405 , with the female share being $39 \%$.

\footnotetext{
An individual is working full-time if his/her regular weekly working time is over 30 hours.

3 In some cases, the number of observations is lower due to the missing values of certain variables.
} 


\subsection{The Hierarchy}

Examination of careers where the different career moves are based on the observed changes in a worker's position in the hierarchy sets high demands for the data, especially if the analysis covers career dynamics both inside and between firms. It requires detailed and consistent data on jobs across firms. This is one of the advantages of the EK data over the datasets used in most of the earlier studies on careers. The EK data include 75 different job titles, and the same job titles are in use in every member firm of EK. Therefore, our job classification, to the extent it is in general possible, is comparable across firms. As part of its data-gathering process, EK provides a detailed description of the features of these jobs. For example, there is information on the level of education and work experience required for the job in question, whether the job contains managerial duties and financial responsibilities, whether the operational environment is dynamic and complex or whether the job is instead comprised of more or less repetitive tasks.

We apply the descriptions of jobs to sort them into six hierarchical levels. The top of the hierarchy consists of managerial jobs associated with financial responsibility and administrative duties. Jobs that require a substantial expertise and in which the operational environment is complex are allocated to the second level. The third level also includes expertise jobs associated with varying operational environments, but in which the required level of prior experience is lower than in jobs at the second level. Jobs at the fourth level require a reasonable level of expertise acquired either through formal education or through work experience, but the problems to be solved are less complex than in jobs higher in the hierarchy. The second-to-last level includes jobs for which some prior work experience is needed, but for which the tasks are repetitive in nature. The bottom of the hierarchy consists of routine jobs with low educational requirements involving repetitive and simple tasks.

Because we observe the hierarchical structures of firms, we are able to define promotion as a transition from a lower hierarchical level to a higher position. This is consistent with the theoretical studies of careers and their definitions of promotions (e.g. Bernhardt 1995). However, many of the previous studies must have settled for other ways of measuring promotions. One typical approach has been to rely on self-reported evaluation (e.g. McCue 1996). A major drawback of this measure is that it is subjective. Pergamit and Veum (1999) also show that for a large share of employees, self-reported promotions are not associated with a change in position. Additionally, movement from a job with a lower average wage to a job with a higher average wage has often been interpreted as indicating a promotion (e.g. Lazear 1992). However, when the relationship between promotions and wage growth is considered, it becomes clear that the use of this measure invites some obvious endogeneity problems.

Before we proceed with describing the resulting hierarchy and how white-collar employees move between levels, we offer two general comments on the hierarchy. First, the CEO and other top management (the executive team) are not included in our hierarchy. Second, it should be noticed that in our paper the hierarchical levels are based on job titles and their descriptions without any reference to wages. This diminishes the endogeneity problems related to the examination of the wage effects of level changes compared to the case where hierarchies are constructed using information on average wages of jobs. Finally, because the same job titles and their descriptions are used in every member firm of EK, we can investigate different career moves both within and between firms. 


\subsection{Some descriptive results}

Figure 1 presents the relative size of levels in different years over the period of 1981-2006. As expected, the relative size of levels increases as we move downwards from the top of the hierarchy, except for level six. As described above, this level contains routine tasks, and because white-collar employees are, on average, fairly highly educated, relatively few of them are in level-six jobs. Another observation from Figure 1 concerns changes in the structure of the hierarchy over time. The biggest change has occurred in the middle of the hierarchy. The relative size of levels two and three has increased mainly at the expense of levels four and five. There are two main reasons for these changes. One is the increase in the average level of schooling in Finland over the last two decades. The other is the structural change of the Finnish economy that has taken place during the observation period, most notably the rapid growth of knowledge-intensive sectors, like the ICT sector.

Figure 1 Size distribution of hierarchical levels, \%

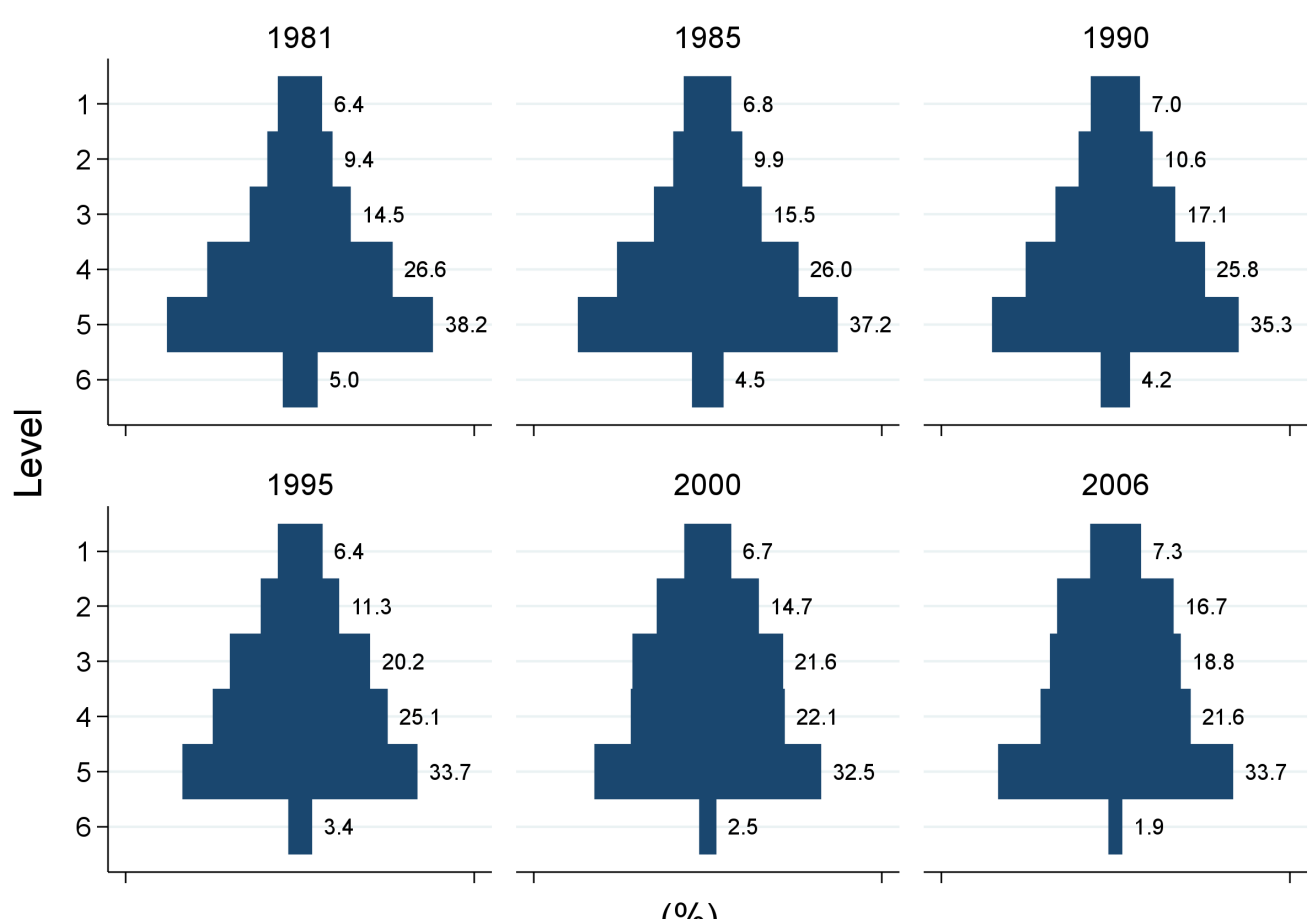

$(\%)$

Table 1 compares a white-collar worker's current hierarchical position to his standing in the hierarchy in the next observation. In line, for example, with Baker et al. (1994), a clear majority of white-collar employees remain at the same level. Table 1 also indicates that promotions are more typical than demotions, although demotions are by no means rare. ${ }^{4} \mathrm{~A}$ similar finding is made by Belzil and Bognanno (2008), Seltzer and Merrett (2000) and Dohmen et al. (2004). Finally, when a white-collar worker is promoted, it is most typical to move up only one hierarchical level at a time.

$4 \quad$ Demotions might be, for example, due to job rotation within firms, although there are also other potential reasons for demotions (see e.g. Bernhardt 1995). 


\begin{tabular}{lccccccr} 
Table 1 & \multicolumn{7}{c}{ Transitions between hierarchical levels, $\%$} \\
Level $t$ & 1 & 2 & 3 & 4 & 5 & 6 & $N$ \\
1 & 91.88 & 3.78 & 1.95 & 1.59 & 0.8 & 0.01 & 194,391 \\
2 & 3.29 & 90.5 & 3.47 & 1.62 & 1.11 & 0.01 & 348,407 \\
3 & 1.12 & 4.61 & 89.91 & 2.33 & 1.97 & 0.06 & 530,243 \\
4 & 0.91 & 1.71 & 3 & 91.59 & 2.71 & 0.09 & 727,705 \\
5 & 0.33 & 0.8 & 1.91 & 2.8 & 93.67 & 0.49 & $1,029,208$ \\
6 & 0.03 & 0.14 & 0.68 & 1.29 & 8.01 & 89.84 & 101,699 \\
\hline
\end{tabular}

Note:

Table 1 presents all transitions between hierarchical levels (both within and between firms) among those with at least two observations.

Several earlier studies have documented a systematic relationship between job transitions and worker's age. For example, da Silva and Van der Klaauw (2005) and Francesconi (2001) show that mobility declines with age. This also appears to be the case in our data, as suggested by Table 2, which shows frequencies of different career moves by age. ${ }^{5}$ About $88 \%$ of white-collar employees younger than 36 years of age neither change an employer nor hierarchical level between two consecutive observations. The corresponding figure for those older than 50 years of age is over $93 \%$. This tendency of declining mobility rates with age holds irrespective of the type of career move, although it is most apparent for internal promotions. Table 2 further shows that most of the employer changes are lateral movements without changes in hierarchical position. ${ }^{6}$ Finally, the table shows that for older white-collar employees, promotions and demotions are almost equally likely.

\begin{tabular}{|c|c|c|c|c|c|c|}
\hline \multirow[t]{3}{*}{ Table 2} & \multicolumn{6}{|c|}{ Career moves by age, $\%$} \\
\hline & \multicolumn{3}{|c|}{ Same Firm } & \multicolumn{3}{|c|}{ Firm Changes } \\
\hline & Same Level & Promotion & Demotion & Same Level & Promotion & Demotion \\
\hline$<26$ & 87.69 & 5.47 & 1.98 & 3.24 & 1.03 & 0.58 \\
\hline $26-30$ & 86.16 & 6.08 & 2.26 & 3.30 & 1.40 & 0.80 \\
\hline $31-35$ & 88.26 & 5.02 & 2.15 & 2.88 & 1.03 & 0.67 \\
\hline $36-40$ & 90.38 & 3.91 & 1.95 & 2.63 & 0.66 & 0.46 \\
\hline $41-45$ & 91.72 & 3.03 & 1.77 & 2.71 & 0.43 & 0.34 \\
\hline $46-50$ & 92.74 & 2.38 & 1.71 & 2.66 & 0.27 & 0.24 \\
\hline $51-55$ & 93.58 & 1.94 & 1.68 & 2.42 & 0.19 & 0.19 \\
\hline $56-60$ & 94.44 & 1.62 & 1.56 & 2.15 & 0.13 & 0.10 \\
\hline$>60$ & 95.44 & 1.33 & 1.47 & 1.63 & 0.06 & 0.07 \\
\hline
\end{tabular}

\footnotetext{
Many studies have reported systematic differences in career moves by gender as well. Therefore, we also investigated distribution of career moves separately for men and women. We found significant gender differences in mobility patterns. For example, men are generally more mobile both within firms and between firms than women. Furthermore, men are more likely to be promoted. However, also demotions are more typical for men than for women.

$6 \quad$ We identify employer changes by comparing firm identifiers attached to white-collar employees across years. However, there are some (rare) cases due to business reorganizations where a worker's firm identifier changes, even though a worker does not actually move between employers. To identify a real firm change, we further require that at least $50 \%$ of the present co-workers must have changed between years t and t-1.
} 


\section{Table 3 Career and level characteristics}

\begin{tabular}{|c|c|c|c|c|c|c|}
\hline Number of outside entrants & 16,552 & 143,326 & 91,580 & 68,837 & 40,218 & 19,305 \\
\hline Percent with 1 year careers & 0.31 & 0.23 & 0.19 & 0.18 & 0.21 & 0.22 \\
\hline Percent with 2 year careers & 0.15 & 0.14 & 0.14 & 0.14 & 0.15 & 0.15 \\
\hline Percent with 5-10 year careers & 0.23 & 0.28 & 0.30 & 0.32 & 0.31 & 0.30 \\
\hline \multicolumn{7}{|l|}{ Of which } \\
\hline Percent holding 1 title & 0.62 & 0.59 & 0.57 & 0.50 & 0.53 & 0.52 \\
\hline Percent holding 2 titles & 0.22 & 0.24 & 0.23 & 0.27 & 0.26 & 0.25 \\
\hline Percent holding 3 titles & 0.10 & 0.11 & 0.12 & 0.13 & 0.13 & 0.14 \\
\hline Percent holding 4 titles & 0.04 & 0.04 & 0.05 & 0.06 & 0.06 & 0.06 \\
\hline Percent holding $5+$ titles & 0.03 & 0.02 & 0.03 & 0.03 & 0.02 & 0.02 \\
\hline Percent with $10+$ year careers & 0.14 & 0.15 & 0.17 & 0.16 & 0.12 & 0.13 \\
\hline \multicolumn{7}{|l|}{ Of which } \\
\hline Percent holding 1 title & 0.62 & 0.59 & 0.57 & 0.51 & 0.56 & 0.56 \\
\hline Percent holding 2 titles & 0.21 & 0.23 & 0.23 & 0.26 & 0.24 & 0.23 \\
\hline Percent holding 3 titles & 0.10 & 0.10 & 0.11 & 0.13 & 0.12 & 0.12 \\
\hline Percent holding 4 titles & 0.04 & 0.04 & 0.05 & 0.06 & 0.05 & 0.06 \\
\hline Percent holding $5+$ titles & 0.03 & 0.03 & 0.03 & 0.04 & 0.03 & 0.04 \\
\hline Average age of new hires (from other firms) & 38.27 & 38.34 & 39.19 & 37.63 & 39.02 & 40.66 \\
\hline Average work experience of new hires (from other firms) & 17.75 & 15.94 & 15.34 & 12.51 & 13.46 & 15.03 \\
\hline Average years of schooling of new hires (from other firms) & 11.44 & 12.82 & 13.88 & 15.43 & 15.92 & 15.70 \\
\hline Average age of new hires (data entrants) & 27.50 & 31.36 & 32.25 & 31.50 & 34.48 & 37.09 \\
\hline Average work experience of new hires (data entrants) & 7.25 & 9.39 & 9.10 & 7.51 & 10.01 & 12.71 \\
\hline Average years of schooling of new hires (data entrants) & 11.60 & 12.66 & 13.60 & 14.67 & 15.08 & 14.72 \\
\hline Avera & 35.18 & 36.86 & 37.67 & 37.13 & 37.95 & 39.17 \\
\hline Average work experience of new hires & 14.69 & 14.26 & 14.30 & 12.84 & 12.89 & 13.85 \\
\hline Average years of schooling of new hires & 11.44 & 13.05 & 13.61 & 14.60 & 15.42 & 15.52 \\
\hline Number of person years in level & 123,152 & $1,232,420$ & 855,698 & 631,719 & 427,133 & 233,603 \\
\hline Percent of entrants into level who are new hires & $77 \%$ & $81 \%$ & $72 \%$ & $63 \%$ & $54 \%$ & $52 \%$ \\
\hline \multicolumn{7}{|l|}{ Exit rate per year } \\
\hline Exit rate per year (internal exits) & $5 \%$ & $4 \%$ & $5 \%$ & $5 \%$ & $5 \%$ & $4 \%$ \\
\hline Exit rate per year (external exits) & $2 \%$ & $3 \%$ & $3 \%$ & $3 \%$ & $3 \%$ & $4 \%$ \\
\hline Exit rate per year (data exits) & $12 \%$ & $9 \%$ & $8 \%$ & $7 \%$ & $8 \%$ & $8 \%$ \\
\hline
\end{tabular}

Table 3, which draws on Baker et al. (1994), presents descriptive statistics on careers. The upper part of the table investigates the length of careers of those entering a firm during the period of 1981-1995, whereas the lower part, which is analyzed in Section 4, provides information on the average characteristics of hires into firms together with the rates of external hiring and exit rates across levels. The main observation made from the upper part of Table 3 is that careers within firms are indeed important. Similar to Baker et al., a significant number of employees spend a long time at a given firm, and they hold many titles during their stay at the firm. For example, of those who enter levels 5 or 4 , roughly $25 \%$ spend more than 10 years with the same firm, and $53 \%$ of these workers hold three or more titles within the firm.

Overall, the results in Tables 1-3 are well in line with the existing literature on careers. We take this as evidence that our job hierarchy is meaningful. 


\section{$4 \quad$ Ports of entry and exit}

As discussed in Section 2, ports of entry and exit are important elements of internal labor markets. This section examines the patterns of hiring and separations in our data. The lower part of Table 3 presents summary statistics of age, years of schooling, and labor market experience, together with data on the shares of internal and external hires across hierarchical levels. There are three different ways to enter the hierarchical level in the EK data. First, an employee can move into his current level internally, either through promotion or demotion (internal entrant). Second, an employee can be hired into a level outside the firm from another member firm of EK (external entrant). Third, a white-collar worker can be recruited outside the data (data entrant). ${ }^{7}$ Although the theory of internal labor market separates only internal hires from those entering the level outside the firm, we further distinguish between the two different groups of external hires. The reason for this is that, as we discuss below, those hired outside the data are quite different from the other external hires in terms of human capital-related characteristics. This might affect the level at which these white-collar workers begin their careers, and how their subsequent careers develop.

In line with the theory of internal labor markets, as we move up the hierarchy, the internal hiring increases in importance. For example, at level 5, internal hires account for $19 \%$ of all hires at that level, whereas the corresponding figure at the top of the hierarchy is $48 \%$. However, what is noteworthy in Table 3 is that outside hiring plays such an important role at all levels. Furthermore, external hires are not concentrated at the bottom of the hierarchy, but there is also substantial external hiring at the top of the hierarchy. We thus conclude that the evidence for the existence of ports-of-entry is weak in Finnish manufacturing. This result supports the findings of Baker et al. (1994) and Lazear and Oyer (2004). ${ }^{8}$

Table 3 also shows that external entrants tend to have more general human capital than internal hires at all levels. White-collar employees entering the firm from another EK member firm are typically older and somewhat more educated than internal hires. This implies that firm-specific human capital is important: external hires must accumulate more general human capital to compete with the internally hired. Also this finding is consistent with Baker et al. (1994). Data entrants, on the other hand, are significantly younger and also typically less educated than other hires at all levels, suggesting that there are some unobserved individual characteristics that are also important in the hiring process.

The bottom of Table 3 examines exits from the hierarchical levels. Following Lazear and Oyer (2004), we break those down into exits within firms (internal exits) and exits from firms. Exits from firms are further divided into two categories: exits to another member firm of EK (external exits) and exits from the data (data exits). Similar to Baker et al. (1994), the evidence for ports of exit is even weaker than that for ports of entry. Internal exit rates are very similar across hierarchical levels without a clear pattern. The same also holds true, to a certain extent,

\footnotetext{
This group includes those who come to the labor market for the first time, were previously working for an employer that is not affiliated with EK, or were previously outside the labor market.

8 The share of external hires reported in Table 3 is much higher than the corresponding figure in Baker et al. (1994). This is probably due to the small size of firms in our data. In Baker et al., the firm under investigation had over 5,000 management employees in the last observation year, whereas in our data, the average size of a firm in 2006 was only 90 (calculated as a number of white-collar employees in a firm).
} 
for external exits, although exits from the top of the hierarchy are, in this case, somewhat more common than exits from the bottom of the hierarchy. For the data exits, on the other hand, exit rates decrease as we move up in the hierarchy.

To conclude, Table 3 does not find strong evidence for the existence of ports of entry and exit. ${ }^{9}$ It thus seems that external competition plays a role in the functioning of internal labor markets among the firms in Finnish manufacturing. This finding supports the findings of Baker et al. (1994) and Treble et al. (2001). This is also in line with the theory of Gibbons and Waldman $(1999,2006)$ because in their theory, the key aspects of internal labor markets, firm-specific human capital and long-term contracts, are absent. Strong evidence in favor of internal labor markets would thus not be consistent with their modeling strategy.

\section{$5 \quad$ Careers after entry}

Table 3 shows that white-collar employees often spend a long time at a particular firm. Thus, careers within firms are important in Finnish manufacturing. Therefore, in this section we take a closer look at internal labor markets by examining employees' mobility between hierarchical levels and factors affecting mobility. The first part of the section focuses exclusively on career moves within firms, but because mobility between employers is also typical in our data and thus forms an important part of employees' careers, the second part analyzes changes in hierarchical position with employer changes.

Table 4, which also follows the paper by Baker et al. (1994), examines career progression within firms among those who have entered level 4 during the period of $1981-1995 .{ }^{10}$ Every worker analyzed in the table has thus had a chance to spend at least 10 years at a firm. We distinguish between internal entrants, entrants from the other member firms, and data entrants. This is because we aim to investigate how outside hires compare with incumbents in terms of subsequent career development. If firm-specific human capital is important to career progression, then we would expect incumbents to fare better than those coming from outside the firm. On the other hand, as Table 3 shows, external hires typically have more general human capital than those hired from inside the firm. This might help external hires to compete with incumbents.

In contrast to Baker et al. (1994), we do not find that hires from outside the firm fare initially better than incumbents. If anything, incumbents are promoted more quickly than external or data entrants in our data. For example, after two years since entering level 4, 9.9\% of the surviving incumbents have been promoted to levels $1-3$, whereas the corresponding figure for external entrants is $8.4 \%$. In addition, in the longer term, a larger share of surviving internal entrants tends to be at higher levels compared to external entrants. However, the gap in promotion rates between the surviving data entrants and incumbents disappears quickly with time. Already, after two years since entry into level 4, the fraction of surviving data entrants at high-

\footnotetext{
It should be noticed that we have not restricted the sample to firms that have employees at each hierarchical level. Although ove $82 \%$ of firms in our data have all six hierarchical levels, there are a few small firms with only one or two levels. Therefore, we examined the robustness of our results to the number of levels represented at the firm. They proved not to be sensitive in this respect.

10 We have also made the same analysis for those who have entered level 5 without any changes in the conclusions.
} 
er levels is the same as the corresponding fraction for incumbents. The smooth career progression of data entrants is probably at least partly due to the fact that data entrants are much younger than incumbents or external entrants, and as we know from the previous literature, promotion probability is negatively associated with age.

Table 4 also presents information on exit rates. In line with Baker et al. (1994), exit rates are lower for incumbents than for outside hires during the first years since entry into level 4 , although differences in exit rates between the different entrant groups are somewhat lower in our data than in Baker et al. Furthermore, we find that in the longer term, differences in exit rates between incumbents and outside hires become negligible.

Baker et al. (1994) also find that the external entrants have more variability in career outcomes than incumbents. Our results, however, indicate the opposite. As can be seen from the bottom part of Table 4, the variance of level attainment is higher for internal entrants than for outside hires, especially during the first years after entry into level 4 . This probably reflects the fact that outside hires have longer work experience. In terms of the Gibbons and Waldman model, labor markets' knowledge of workers' ability increases with work experience, and therefore,

\begin{tabular}{|c|c|c|c|c|c|c|c|c|c|c|c|c|}
\hline \multicolumn{13}{|c|}{ Table 4} \\
\hline \multirow{2}{*}{\multicolumn{13}{|c|}{ Current }} \\
\hline & & & & & & & & & & & & \\
\hline \multirow{2}{*}{ level } & Statistic & & 1 & 2 & 3 & 4 & 5 & 6 & 7 & 8 & 9 & 10 \\
\hline & & Internal entrant & & 1.8 & 3.0 & 3.9 & 4.8 & 5.5 & 6.3 & 6.9 & 7.2 & 7.8 \\
\hline \multirow[t]{3}{*}{1} & $\%$ of remaining & External entrant & & 1.5 & 2.5 & 3.5 & 4.3 & 5.2 & 5.6 & 6.2 & 6.6 & 7.8 \\
\hline & & Data entrant & & 1.4 & 2.5 & 3.9 & 4.9 & 5.8 & 6.8 & 7.4 & 8.1 & 9.1 \\
\hline & & Internal entrant & & 3.1 & 5.4 & 6.7 & 8.2 & 9.0 & 10.2 & 11.8 & 13.3 & 14.0 \\
\hline \multirow[t]{3}{*}{2} & $\%$ of remaining & External entrant & & 2.5 & 4.4 & 5.9 & 7.2 & 8.1 & 9.7 & 10.6 & 12.4 & 13.8 \\
\hline & & Data entrant & & 2.7 & 5.0 & 6.9 & 8.6 & 10.4 & 12.1 & 13.7 & 15.0 & 16.1 \\
\hline & & Internal entrant & & 5.0 & 8.3 & 11.0 & 12.8 & 14.2 & 15.6 & 16.2 & 17.0 & 17.6 \\
\hline \multirow[t]{3}{*}{3} & $\%$ of remaining & External entrant & & 4.4 & 7.9 & 10.5 & 12.4 & 14.0 & 15.1 & 15.9 & 17.2 & 18.2 \\
\hline & & Data entrant & & 5.2 & 9.1 & 12.4 & 14.7 & 16.3 & 17.5 & 18.2 & 18.7 & 18.3 \\
\hline & & Internal entrant & 100.0 & 84.1 & 74.8 & 67.9 & 62.3 & 58.3 & 54.0 & 49.4 & 45.5 & 41.3 \\
\hline \multirow[t]{3}{*}{4} & $\%$ of remaining & External entrant & 100.0 & 88.5 & 80.3 & 73.7 & 68.7 & 64.2 & 60.3 & 56.0 & 49.5 & 44.0 \\
\hline & & Data entrant & 100.0 & 86.2 & 75.3 & 68.4 & 62.3 & 57.2 & 52.9 & 47.9 & 43.5 & 39.4 \\
\hline & & Internal entrant & & 5.8 & 8.0 & 9.8 & 11.2 & 12.3 & 13.1 & 14.8 & 16.2 & 18.2 \\
\hline \multirow[t]{3}{*}{5} & $\%$ of remaining & External entrant & & 3.0 & 4.7 & 6.1 & 7.2 & 8.3 & 9.0 & 10.9 & 13.9 & 15.8 \\
\hline & & Data entrant & & 4.4 & 7.8 & 8.1 & 9.2 & 10.0 & 10.4 & 12.5 & 14.6 & 16.7 \\
\hline & & Internal entrant & & 0.4 & 0.5 & 0.7 & 0.8 & 0.7 & 0.9 & 1.0 & 0.9 & 1.1 \\
\hline \multirow[t]{14}{*}{6} & $\%$ of remaining & External entrant & & 0.2 & 0.2 & 0.2 & 0.2 & 0.3 & 0.3 & 0.4 & 0.4 & 0.5 \\
\hline & & Data entrant & & 0.2 & 0.2 & 0.3 & 0.3 & 0.3 & 0.3 & 0.3 & 0.3 & 0.4 \\
\hline & Level (average) & Internal entrant & 4.00 & 3.90 & 3.81 & 3.75 & 3.69 & 3.65 & 3.60 & 3.56 & 3.53 & 3.51 \\
\hline & & External entrant & 4.00 & 3.89 & 3.81 & 3.74 & 3.68 & 3.63 & 3.58 & 3.56 & 3.53 & 3.48 \\
\hline & & Data entrant & 4.00 & 3.90 & 3.82 & 3.71 & 3.63 & 3.56 & 3.49 & 3.45 & 3.42 & 3.40 \\
\hline & Level (variance) & Internal entrant & 0.00 & 0.63 & 0.79 & 0.89 & 0.96 & 1.01 & 1.06 & 1.12 & 1.15 & 1.19 \\
\hline & & External entrant & 0.00 & 0.55 & 0.71 & 0.81 & 0.88 & 0.94 & 0.99 & 1.04 & 1.09 & 1.16 \\
\hline & & Data entrant & 0.00 & 0.57 & 0.76 & 0.87 & 0.95 & 1.01 & 1.06 & 1.11 & 1.16 & 1.21 \\
\hline & Exit rate $\%$ & Internal entrant & 0.10 & 0.11 & 0.11 & 0.10 & 0.10 & 0.10 & 0.10 & 0.10 & 0.10 & 0.10 \\
\hline & & External entrant & 0.12 & 0.12 & 0.12 & 0.10 & 0.11 & 0.11 & 0.10 & 0.11 & 0.10 & 0.12 \\
\hline & & Data entrant & 0.17 & 0.13 & 0.13 & 0.12 & 0.11 & 0.11 & 0.10 & 0.10 & 0.11 & 0.12 \\
\hline & $\mathrm{N}$ & Internal entrant & 19,843 & 17,884 & 15,991 & 14,290 & 12,790 & 11,545 & 10,367 & 9,322 & 8,374 & 7,496 \\
\hline & & External entrant & 16,451 & 14,514 & 12,831 & 11,259 & 10,083 & 9,006 & 8,006 & 7,205 & 6,446 & 5,798 \\
\hline & & Data entrant & 41,122 & 34,043 & 29,496 & 25,553 & 22,570 & 20,006 & 17,889 & 16,012 & 14,356 & 12,840 \\
\hline
\end{tabular}


experienced workers should move with lower probability after allocation to a given level compared to employees with shorter work experience.

Overall, Table 4 shows that there is significant variation in career development between whitecollar employees. For example, some employees are able to move from the lower ranks of the hierarchy to management, whereas some remain stuck at the bottom of the organizational ladder. This invites one to ask further questions about career development within firms. For example, is there evidence of fast-tracks in Finnish manufacturing? What happens to those who experience sluggish career progress? Are they more likely to leave a firm?

\subsection{Fast track promotions and exits}

These questions are investigated in Table 5, which again draws on Baker et al. (1994). Rows show the time spent at level 5 before promotion to level 4, whereas columns present promotion and exit rates by different levels of tenure at level 4 . To simplify the analysis, we focus on levels 5 and 4, which are the two largest levels measured by employment shares in our data. Furthermore, here, we do not separate between the different entrant groups mainly because the sample size would be too small.

Similar to Baker et al. (1994) and Treble et al. (2001), we find evidence of fast-tracks. Given current tenure at level 4, promotion rates decrease with time spent at level 5. For example, white-collar employees who were promoted to level 4 after only one year at level 5 have an $18 \%$ promotion probability during their first year at level 4 , whereas for those who spent an additional year at level 5 , the promotion rate is $14 \%$. Thus, those who are promoted more quickly at level 5 also have better chances of being promoted quickly at level 4 .

\begin{tabular}{|c|c|c|c|c|c|c|c|c|c|c|c|}
\hline \multirow[b]{3}{*}{ Years at level 5} & \multicolumn{11}{|c|}{ Fime to promotion in level 5 versus promotion and exits rates in level 4} \\
\hline & & \multicolumn{10}{|c|}{ Years at level 4 before promotion or exit } \\
\hline & & 1 & 2 & 3 & 4 & 5 & 6 & 7 & 8 & 9 & 10 \\
\hline \multirow[t]{3}{*}{1} & Promotion rate \% & 18 & 16 & 14 & 9 & 8 & 9 & 9 & 7 & 7 & 6 \\
\hline & Exit rate $\%$ & 17 & 16 & 14 & 12 & 12 & 13 & 10 & 13 & 15 & 12 \\
\hline & $\mathrm{N}$ & 10,796 & 7,598 & 5,296 & 3,890 & 2,789 & 2,192 & 1,584 & 1,231 & 930 & 2,921 \\
\hline \multirow[t]{3}{*}{2} & Promotion rate \% & 14 & 14 & 10 & 8 & 8 & 10 & 9 & 9 & 6 & 5 \\
\hline & Exit rate \% & 16 & 15 & 13 & 14 & 12 & 14 & 11 & 14 & 12 & 10 \\
\hline & $N$ & 5,769 & 4,060 & 3,022 & 2,010 & 1,561 & 1,215 & 943 & 767 & 591 & 2,168 \\
\hline \multirow[t]{3}{*}{3} & Promotion rate $\%$ & 13 & 12 & 9 & 9 & 6 & 9 & 6 & 6 & 9 & 5 \\
\hline & Exit rate \% & 12 & 14 & 14 & 12 & 10 & 12 & 11 & 14 & 14 & 9 \\
\hline & $\mathrm{N}$ & 3,807 & 2,673 & 1,928 & 1,433 & 1,117 & 897 & 732 & 591 & 460 & 1,623 \\
\hline \multirow[t]{3}{*}{4} & Promotion rate $\%$ & 13 & 10 & 10 & 9 & 7 & 11 & 8 & 7 & 3 & 4 \\
\hline & Exit rate $\%$ & 12 & 14 & 12 & 12 & 11 & 11 & 11 & 12 & 11 & 9 \\
\hline & $\mathrm{N}$ & 2,477 & 1,757 & 1,334 & 979 & 757 & 587 & 465 & 366 & 286 & 1,085 \\
\hline \multirow[t]{3}{*}{5} & Promotion rate \% & 12 & 6 & 10 & 11 & 6 & 10 & 4 & 8 & 6 & 5 \\
\hline & Exit rate \% & 13 & 14 & 12 & 12 & 15 & 15 & 11 & 12 & 10 & 8 \\
\hline & $\mathrm{N}$ & 1,694 & 1,257 & 980 & 728 & 576 & 459 & 350 & 274 & 209 & 797 \\
\hline \multirow[t]{3}{*}{6} & Promotion rate $\%$ & 13 & 8 & 5 & 11 & 7 & 7 & 2 & 5 & 6 & 3 \\
\hline & Exit rate $\%$ & 13 & 12 & 13 & 17 & 9 & 16 & 9 & 8 & 6 & 10 \\
\hline & $\mathrm{N}$ & 1,311 & 977 & 780 & 604 & 442 & 354 & 280 & 238 & 203 & 752 \\
\hline \multirow[t]{3}{*}{$7+$} & Promotion rate $\%$ & 9 & 7 & 7 & 7 & 4 & 8 & 3 & 5 & 4 & 3 \\
\hline & Exit rate \% & 12 & 12 & 12 & 12 & 11 & 9 & 8 & 10 & 10 & 11 \\
\hline & N & 4,110 & 3,035 & 2,355 & 1,784 & 1,378 & 1,061 & 841 & 689 & 547 & 1,349 \\
\hline
\end{tabular}


Baker et al. (1994) and Treble et al. (2001) also find evidence of a phenomenon that they call the fast-track exit effect. Under fast-track exits, individuals promoted quickly have higher exit rates as well. Our results offer some support for the existence of fast-track exits, although exit rates do not vary as strongly by time spent in the previous hierarchical level in our data as they do in Baker et al. and Treble et al. As Table 5 shows, those white-collar employees who were promoted during the first year at level 5 have a $17 \%$ exit rate in the first year at level 4 vs. $12 \%$ for those from whom it took 3 years to get promoted to level 4 . One explanation for this phenomenon offered by Baker et al. (1994) is that some high-ability individuals may not find the best possible job for themselves at their current employer, or they are not paid according to their expected marginal product, and therefore, they are more likely to leave the firm. A more detailed analysis shows that most $(69 \%)$ of the fast-track exits also leave the data. Of those who move to another EK member firm, 26\% are promoted, 57\% remain at the same level, and 16\% are demoted. Thus, there is considerable heterogeneity in career progression for this group. This may reflect differences in reasons for exit. Some may leave the firm, for example, due to downsizing, whereas others may leave for better outside offers.

\subsection{Promotions, exits and position in wage hierarchy}

Table 6 continues to examine promotions by showing statistics on white-collar employees' relative wage position within hierarchical levels before and after promotion. ${ }^{11}$ It thus gives us fur-

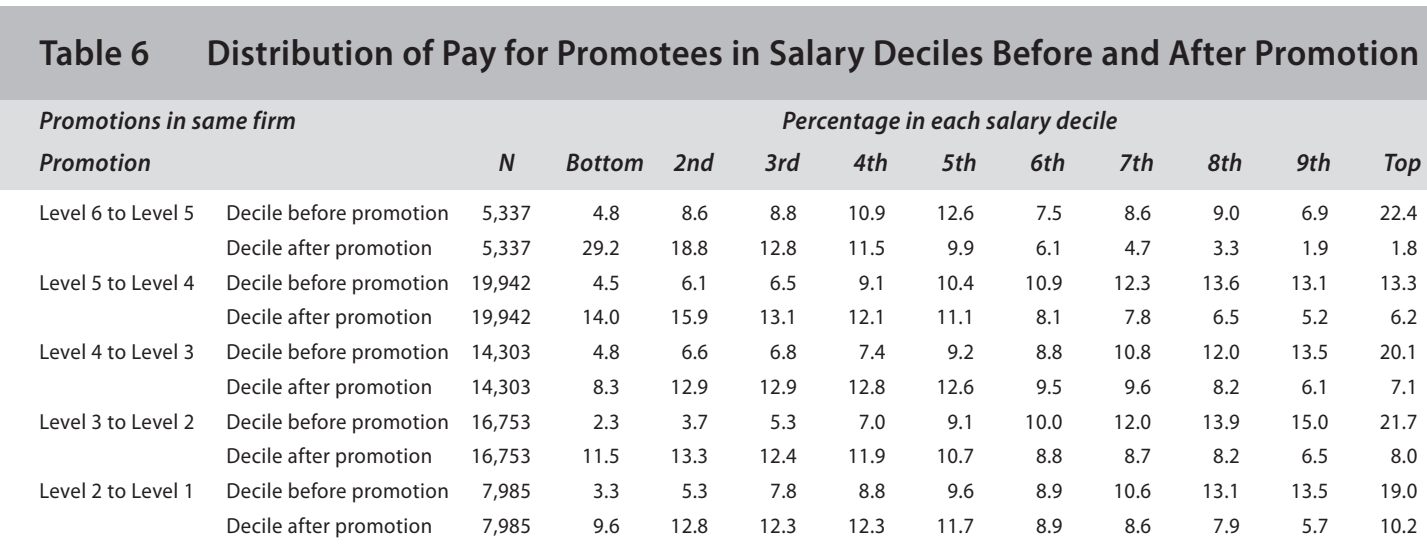

\begin{tabular}{|c|c|c|c|c|c|c|c|c|c|c|c|c|}
\hline \multirow{2}{*}{\multicolumn{2}{|c|}{$\begin{array}{l}\text { Promotions in other firm } \\
\text { Promotion }\end{array}$}} & \multicolumn{11}{|c|}{ Percentage in each salary decile } \\
\hline & & \multirow{2}{*}{$\begin{array}{l}N \\
671\end{array}$} & \multirow{2}{*}{$\begin{array}{c}\text { Bottom } \\
6.3\end{array}$} & \multirow{2}{*}{$\begin{array}{l}\text { 2nd } \\
11.0\end{array}$} & \multirow{2}{*}{$\begin{array}{l}3 r d \\
9.2\end{array}$} & \multirow{2}{*}{$\begin{array}{r}4 \text { th } \\
12.4\end{array}$} & \multirow{2}{*}{$\begin{array}{r}5 \text { th } \\
11.8\end{array}$} & \multirow{2}{*}{$\begin{array}{l}6 \text { th } \\
7.5\end{array}$} & \multirow{2}{*}{$\begin{array}{r}7 \text { th } \\
7.3\end{array}$} & \multirow{2}{*}{$\begin{array}{r}8 \text { th } \\
7.9\end{array}$} & \multirow{2}{*}{$\begin{array}{l}9 \text { th } \\
7.2\end{array}$} & \multirow{2}{*}{$\begin{array}{r}\text { Top } \\
19.5\end{array}$} \\
\hline Level 6 to Level 5 & Decile before promotion & & & & & & & & & & & \\
\hline & Decile after promotion & 671 & 24.3 & 21.6 & 11.5 & 12.8 & 8.6 & 6.6 & 6.4 & 3.3 & 1.2 & 3.7 \\
\hline \multirow[t]{2}{*}{ Level 5 to Level 4} & Decile before promotion & 2,799 & 4.9 & 6.1 & 7.1 & 9.2 & 10.8 & 12.1 & 13.6 & 12.3 & 11.4 & 12.6 \\
\hline & Decile after promotion & 2,799 & 12.7 & 14.1 & 12.5 & 11.1 & 10.1 & 8.0 & 7.7 & 7.9 & 5.8 & 10.1 \\
\hline \multirow[t]{2}{*}{ Level 4 to Level 3} & Decile before promotion & 2,781 & 5.8 & 7.8 & 7.7 & 9.4 & 9.9 & 9.4 & 11.3 & 11.8 & 10.8 & 16.1 \\
\hline & Decile after promotion & 2,781 & 6.7 & 11.8 & 11.5 & 12.9 & 13.7 & 9.5 & 9.5 & 8.3 & 7.3 & 8.8 \\
\hline \multirow[t]{2}{*}{ Level 3 to Level 2} & Decile before promotion & 2,599 & 3.5 & 6.2 & 7.5 & 9.7 & 10.4 & 9.4 & 11.2 & 11.0 & 12.9 & 18.2 \\
\hline & Decile after promotion & 2,599 & 4.9 & 10.4 & 10.7 & 12.2 & 12.2 & 10.3 & 10.2 & 8.9 & 7.0 & 13.1 \\
\hline \multirow[t]{2}{*}{ Level 2 to Level 1} & Decile before promotion & 1,271 & 4.8 & 10.5 & 10.5 & 8.4 & 10.9 & 9.7 & 9.7 & 11.3 & 10.5 & 13.8 \\
\hline & Decile after promotion & 1,271 & 6.7 & 10.7 & 11.2 & 10.2 & 10.4 & 8.5 & 9.1 & 8.5 & 7.3 & 17.4 \\
\hline
\end{tabular}

Wage deciles are calculated within hierarchical levels and firms for each year. 
ther information on what types of employees are promoted. To examine whether there are any differences in the relationship between promotions and an individual's position in the wage distribution between internal and external promotions, we separate those who are promoted within a firm from those who are promoted with an employer change.

Table 6 shows that there is a great deal of variation in terms of the wage deciles from which individuals are promoted and to which deciles they end up with after the promotion. Similar to Baker et al. (1994), there is some tendency for those who are promoted to be at the upper end of the wage distribution before promotion and at the lower end of the distribution after promotion. For example, $21.7 \%$ of those promoted from level 3 to level 2 come from the highest decile, versus $2.3 \%$ from the bottom of the wage distribution. On the other hand, $24.8 \%$ of these white-collar employees enter at the lowest two deciles of level 2, whereas only $14.5 \%$ go to the highest two deciles. This pattern holds for both internal and external promotions. Nevertheless, some differences in the promotion process can be observed between the two groups of promotees. Most notably, employees who are promoted when changing an employer are more likely to come from the lower wage deciles, but they enter more often at the upper end of the wage distribution than those who are promoted from inside firms. The model of Gibbons and Waldman predicts that most, but not all, of the promotees from a given level should come from the upper end of the wage distribution. This follows because the employees in the upper part of the wage distribution are also closest to the threshold for promotion in terms of on-the-job human capital. However, large positive updates to expected ability lead some employees, who were formerly further away from the threshold, to be promoted.

Following Baker et al. (1994), we also examine exit rates by hierarchical level and wage decile. Matching models would predict that exit rates decrease in the wage deciles, as poor quality employee-employer matches are more likely to be terminated. However, as can be seen from Table 7, this is not what we observe in our data. If anything, exit rates are higher at the top of the wage distribution. This finding is consistent with the results presented by Treble et al. (2001), but in contrast to Baker et al. Treble et al. suggest that there might be promotion bottlenecks within firms that cause some of the high-ability employees to leave the firm.

\begin{tabular}{|c|c|c|c|c|c|c|c|c|c|c|c|}
\hline \multirow[t]{3}{*}{ Table 7} & \multicolumn{11}{|c|}{ Exit rates by hierarchical level and wage decile (all exits) } \\
\hline & \multicolumn{11}{|c|}{ Percentage in each salary decile } \\
\hline & $N$ & Bottom & 2nd & $3 r d$ & 4 th & 5 th & 6 th & 7 th & 8 th & 9 th & Top \\
\hline Level 6 & 15,864 & 6.2 & 10.0 & 9.3 & 10.6 & 12.9 & 6.8 & 8.7 & 8.2 & 6.2 & 21.2 \\
\hline Level 5 & 163,741 & 9.5 & 10.2 & 9.6 & 10.1 & 10.3 & 9.2 & 9.6 & 9.8 & 9.4 & 12.3 \\
\hline Level 4 & 110,078 & 8.8 & 10.1 & 9.9 & 10.2 & 10.6 & 9.2 & 9.5 & 9.6 & 8.9 & 13.2 \\
\hline Level 3 & 83,883 & 8.3 & 9.9 & 9.5 & 10.2 & 10.5 & 9.0 & 9.6 & 9.6 & 9.5 & 14.1 \\
\hline Level 2 & 64,532 & 8.0 & 9.5 & 9.0 & 9.7 & 10.4 & 8.7 & 9.3 & 9.7 & 9.3 & 16.4 \\
\hline Level 1 & 34,830 & 6.7 & 9.0 & 8.4 & 9.5 & 11.2 & 7.9 & 8.9 & 9.4 & 8.6 & 20.4 \\
\hline
\end{tabular}




\subsection{Regression model for promotion}

Table 8 examines factors behind promotions by estimating the linear regression model. ${ }^{12}$ To allow the explanatory variables to vary between internal and external promotions, we estimate the model separately for inside promotions and promotions associated with an employer change. The dependent variable for within-firm promotions takes a value of one if an individual moves from a lower hierarchical level to a higher one but stays in the same firm between year $t$ and year $t+1$, and zero otherwise. For the other model, the dependent variable is a dummy that takes a value of one if an individual is promoted and changes firms between year $t$ and year $t+1$, and zero otherwise.

Our explanatory variables can be grouped into 5 broad categories. The first category measures an individual's human capital and includes years of education and its square, field of education (nine categories), tenure (four categories), and age (four categories). The second category consists of variables accounting for an individual's earlier career development. We measure prior career with years spent thus far in the current hierarchical level within the same firm and the time spent on the previous hierarchical level within the same firm. Variables controlling for firm characteristics constitute the third category. It includes the number of employees (seven categories) and industry (63 categories). One of the novelties of our study is that we also have data on the characteristics of the co-workers. These characteristics are grouped into the fourth category, which includes years of education, tenure, and gender. If internal promotion competition matters, as in DeVaro (2006), these variables should predict promotion. Finally, we also control for gender, hierarchical level, field of job title, an individual's position in the wage distribution, and year. All explanatory variables are measured at year $t$.

Because promotion probability might be affected by unobserved individual characteristics, which may further be correlated with our explanatory variables, in addition to OLS, we also estimate a fixed effects model, which accounts for time-invariant unobserved individual heterogeneity. Moreover, because firms may apply different standards and rules for promotions, unobserved firm heterogeneity might also matter with respect to promotion probabilities. Therefore, our third model specification includes both individual and firm fixed effects.

Table 8 shows that the level of education is positively associated with both internal and external promotions, which is in line, for example, with the empirical results of Acosta (2010) and the theory of Gibbons and Waldman. When it comes to the relationship between age and promotion, the results indicate that individuals older than 50 years of age are less likely to be promoted than those who are between 30 and 39 years of age. Table 8 also shows that the longer an individual has been at his current hierarchical level or was in the previous level, the less likely he is to be promoted. This supports our earlier conclusions about the existence of fast-tracks. The fixed effects results reverse this conclusion: given individual time-invariant heterogeneity, promotion probability is increasing with tenure at the previous and current levels. This is consistent with the Gibbons and Waldman model because, given equal ability, promotion probability depends on education and work experience. Empirically, this means that time-invariant heterogeneity is correlated with both time spent at a level and promotion probability.

\footnotetext{
12 As discussed, for example, by Angrist and Pischke (2009), using the linear probability model instead of a non-linear one is of little importance, in practice, when the interest is in average marginal effects.
} 


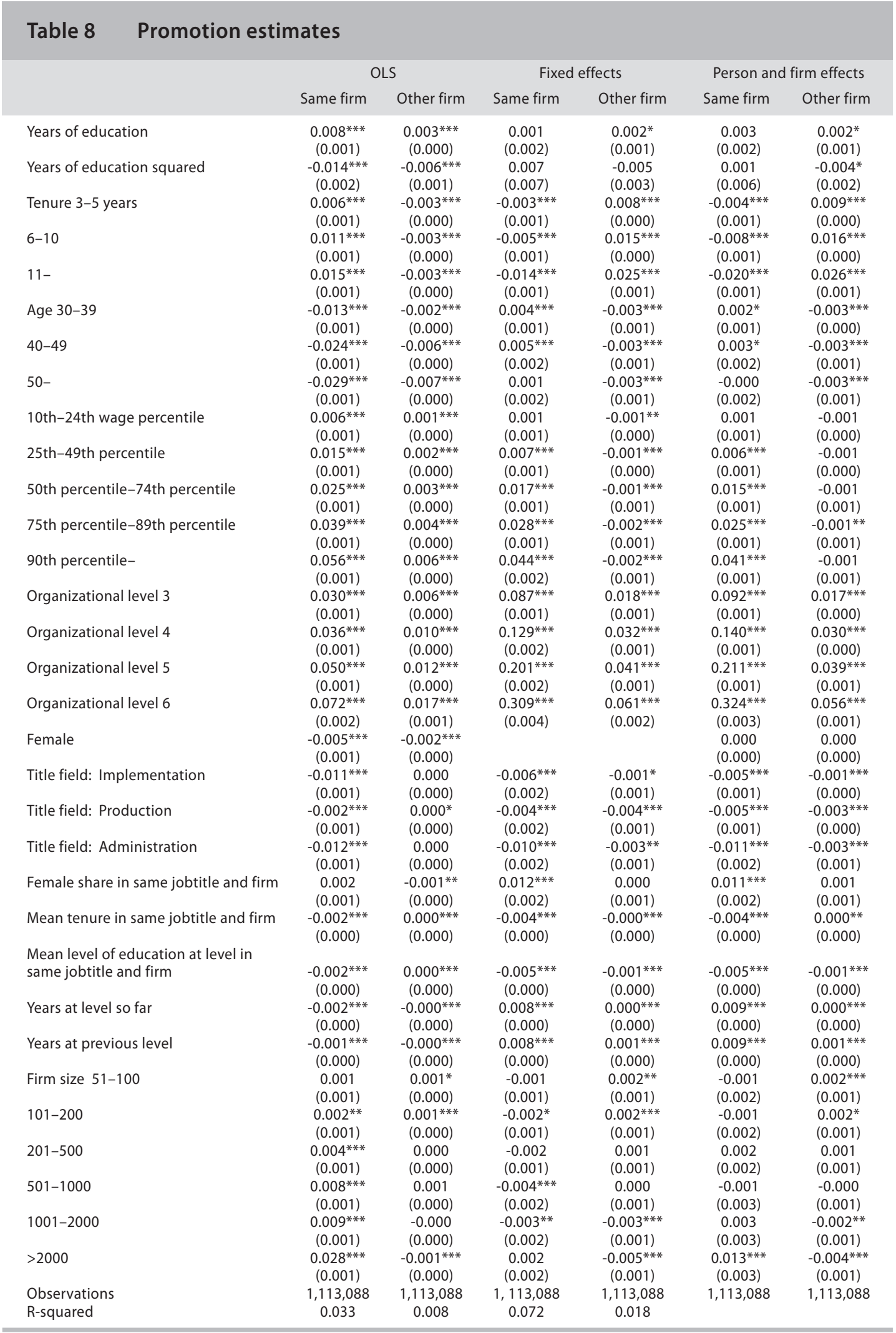

Notes: ${ }^{1)}$ Cluster robust standard errors in OLS and FE models, ${ }^{* * *} p<0.01,{ }^{* *} p<0.05,{ }^{*} p<0.1{ }^{2)}$ Standard errors in the last four columns do not take heteroscedasticity and autocorrelation into account. ${ }^{3)}$ All columns include field of education dummies (eight categories), firm size dummies (six categories), industry dummies (63 categories), and year dummies. 
Our results regarding the correlation between an individual's position in the wage distribution and promotion probability are in line with Table 6 but in contrast to those presented by Acosta (2010), who investigated promotion dynamics using data from a single US firm. Acosta reports that those at the lower deciles in the distribution of wages by occupational category are more likely to be promoted than those higher in the wage distribution. Our results, on the other hand, show that there is a positive relationship between an individual's position in the wage distribution and promotion probability. This result holds for internal promotions in all three estimation methods. ${ }^{13}$ However, accounting for individual fixed effects reverses the results for promotions to other firms.

As expected, promotions are more likely at the bottom of the hierarchy, reflecting the fact that there is more room for promotions at the lower ranks of the hierarchy. We also find that men are more likely to be promoted than women, a result that has been documented in several previous studies (e.g. McCue 1996, Pergamit and Veum 1999, Ransom and Oaxaca 2005, Blau and Devaro 2007). On the other hand, of the role played by the characteristics of the co-workers, there is little earlier empirical evidence. Our results show that an individual has better chances of being promoted within a firm if his co-workers are less educated with little firm tenure. Somewhat surprisingly, the gender of the colleagues turned out to be unrelated to promotion probability. The characteristics of the co-workers are often also significantly correlated with promotions taking place with employer changes, although with opposite signs. This result is consistent with employees who perceive their promotion probability to be low, searching for alternative employment.

Finally, our estimates show that internal promotions are more common in larger firms. This might indicate that larger firms are more likely to rely on internal labor markets with well-defined career paths than smaller firms (Chan 1996). When promotions with employer changes are investigated, the firm size effect is less significant, with a less clear-cut pattern.

\section{$6 \quad$ Careers and wages}

The importance of hierarchical levels in wage determination and the contribution of promotions to wage growth are central questions in the literature on careers in organizations. Therefore, we end our analysis of careers by taking a closer look at wages. We begin by examining changes in the relative wage structure in Finnish manufacturing over the period of 1981-2006, after which we investigate the relative importance of hierarchical levels versus human capital in accounting for variation in wages. We finish by analyzing wage premiums on different career moves.

Figure 2 describes the development of mean hourly wages by hierarchical level over time. Mean hourly wages increase with level, although the difference in mean wages is small between levels 1 and 2. More interestingly, real wages have grown in very similar fashion across levels, leaving the relative wage structure practically unchanged during the investigation peri-

\footnotetext{
Note that even though the coefficients in the columns labeled "other firm" are much smaller, so is the mean of the dependent variable. On average, $4.3 \%$ of individuals are promoted at their current firm in any year, whereas $0.6 \%$ of individuals earn a promotion concurrently with a change in the firm.
} 
Figure 2 Mean hourly wages by hierarchical level, 1981-2006

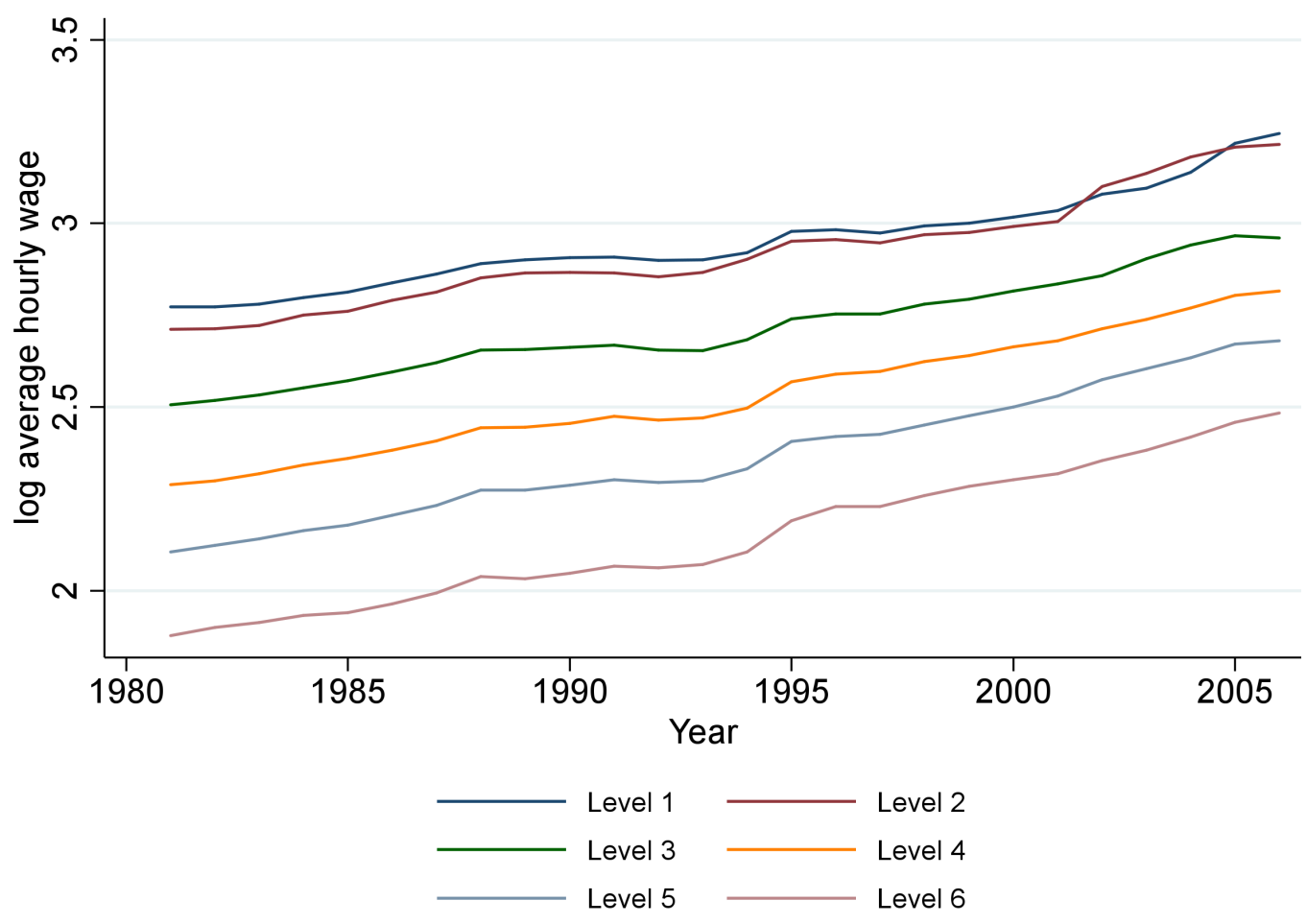

Figure 3 The variation of wages within hierarchical levels

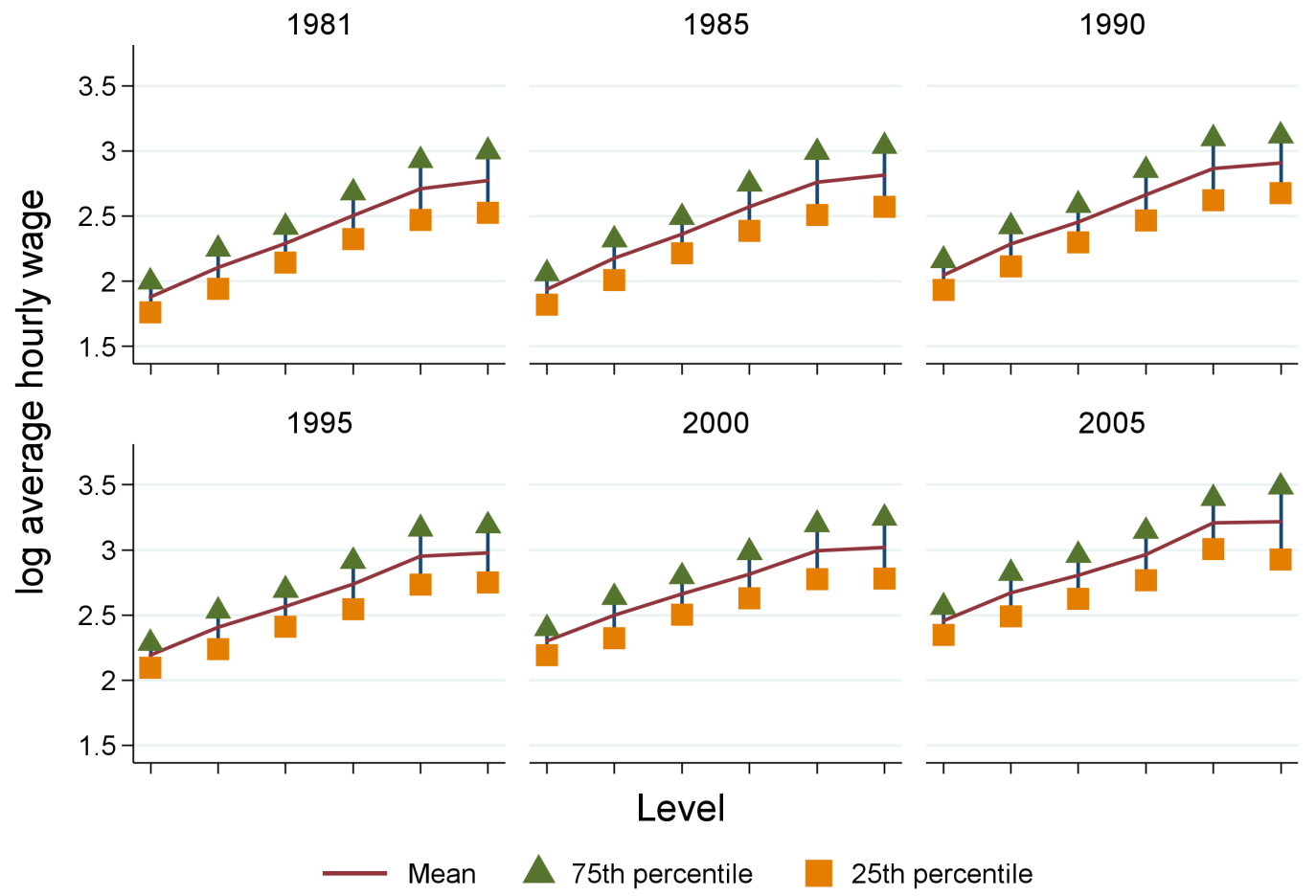


od. As discussed in Baker et al. (1994), this rigidity of wage structure suggests that hierarchical levels play an important role in wage determination.

Figure 3 examines the variation of wages within hierarchical levels by showing the wage ranges by level. Consistent with Baker et al. (1994) and Treble et al. (2001), we observe wages to increase at an increasing rate with hierarchical level (in the figure, $\log$ wages increase linearly). However, at level 2, there is a kink in the wage profile, pointing to smaller wage differentials between levels 2 and 1 compared to other levels. This may reflect the fact that our data do not include CEOs and equivalents. Also similar to Baker et al. and Treble et al., we observe substantial wage overlap between levels. For example, employees at the upper quartile of the wage distribution at level 4 have higher wages than employees at the lower quartile at level 1. In Gibbons and Waldman (2006) model, this is driven by education: employees with a high level of education at a lower level may have larger expected output than employees with lower education at a higher level. The variation of wages within levels implies that wages are not only determined by levels but also by other factors. Finally, wage dispersion has generally remained constant in the Finnish manufacturing sector during the last two decades. The top level, however, is an exception: at level 1, wage dispersion increased somewhat between 2000 and 2005.

Following Baker et al. (1994), in Table 9 we examine in more detail the relative importance of human capital vs. hierarchical levels in accounting for variation in wages. The first two columns include only human capital-related variables as regressors, the next two columns control only for hierarchical levels, and finally, to illustrate how much the explanatory power increases once human capital variables are added to the model including only level variables, columns 5 and 6 show the results for a combined model. Unlike Baker et al. and Treble et al. (2001), we find that human capital explains somewhat more of the variance in wages than hierarchical levels. For example, during the period of 2001-2005, human capital variables explained $46.9 \%$ of the variance, while hierarchical levels accounted for $43.5 \%$ of the variation in wages. We can also observe that the residual variance has increased over time: both human capital variables and hierarchical levels have lost some of their explanatory power during the investigation period, human capital more so than hierarchical levels. Thus, the relative importance of levels has increased over time. ${ }^{14}$

The fact that hierarchical levels are less important determinants of wages in our data compared to the data sets used by Baker et al. and Treble et al can also be observed from the last two columns of Table 9. When we add human capital variables to the specification including only hierarchical levels, there is a considerable increase in the explanatory power, whereas Baker et al. and Treble et al. find only a small increase in $\mathrm{R}^{2}$ as a result of adding human capital variables to the model. Furthermore, in our data, wages vary significantly more between jobs at the same hierarchical level than what Baker et al. find. They report only a $2 \%$ increase in $\mathrm{R}^{2}$ when hierarchical levels are replaced with job titles, whereas we observe $\mathrm{R}^{2}$ to increase approximately $25 \%$ as a result of using job titles as controls in place of hierarchical levels. ${ }^{15}$ These results are quite expected because we study thousands of firms, while Baker et al. and Treble et al. studied only a single firm.

\footnotetext{
14 We also estimated the models for the period of 1991-1995, and the $R^{2}$ for this period falls between the $R^{2} s$ for years $1981-1985$ and 2001-2005.

15 These results are available from the authors upon request.
} 


\begin{tabular}{|c|c|c|c|c|c|c|}
\hline & Humar & capital & & els & Com & bined \\
\hline & $1981-1985$ & $2001-2005$ & $1981-1985$ & $2001-2005$ & $1981-1985$ & 2001-2005 \\
\hline Years of education & $\begin{array}{c}0.106^{* * *} \\
(0.003)\end{array}$ & $\begin{array}{c}0.100^{* * *} \\
(0.002)\end{array}$ & & & $\begin{array}{c}0.073^{* * *} \\
(0.002)\end{array}$ & $\begin{array}{c}0.067^{* * * *} \\
(0.002)\end{array}$ \\
\hline Years of education squared & $\begin{array}{c}-0.050^{* * *} \\
(0.011)\end{array}$ & $\begin{array}{c}-0.107^{* * *} \\
(0.007)\end{array}$ & & & $\begin{array}{c}-0.036^{* * *} \\
(0.008)\end{array}$ & $\begin{array}{c}-0.073^{* * *} \\
(0.006)\end{array}$ \\
\hline Tenure 3-5 years & $\begin{array}{c}0.049 * * * \\
(0.001)\end{array}$ & $\begin{array}{c}0.010^{* * *} \\
(0.001)\end{array}$ & & & $\begin{array}{c}0.041 * * * \\
(0.001)\end{array}$ & $\begin{array}{c}0.013^{* * *} \\
(0.001)\end{array}$ \\
\hline $6-10$ & $\begin{array}{c}0.078^{* * *} \\
(0.001)\end{array}$ & $\begin{array}{c}0.026^{* * *} \\
(0.002)\end{array}$ & & & $\begin{array}{c}0.063^{* * *} \\
(0.001)\end{array}$ & $\begin{array}{c}0.024^{* * *} \\
(0.001)\end{array}$ \\
\hline $11-$ & $\begin{array}{c}0.107^{* * *} \\
(0.002)\end{array}$ & $\begin{array}{c}0.012^{* * *} \\
(0.002)\end{array}$ & & & $\begin{array}{c}0.086^{* * *} \\
(0.001)\end{array}$ & $\begin{array}{c}0.014^{* * *} \\
(0.001)\end{array}$ \\
\hline Age $30-39$ & $\begin{array}{c}0.168^{* * *} \\
(0.001)\end{array}$ & $\begin{array}{c}0.191^{* * *} \\
(0.001)\end{array}$ & & & $\begin{array}{c}0.136 * * * \\
(0.001)\end{array}$ & $\begin{array}{c}0.154^{* * *} \\
(0.001)\end{array}$ \\
\hline $40-49$ & $\begin{array}{c}0.256^{* * *} \\
(0.002)\end{array}$ & $\begin{array}{c}0.282^{* * *} \\
(0.002)\end{array}$ & & & $\begin{array}{c}0.202^{* * *} \\
(0.001)\end{array}$ & $\begin{array}{c}0.231^{* * *} \\
(0.002)\end{array}$ \\
\hline $50-$ & $\begin{array}{c}0.255^{* * *} \\
(0.002)\end{array}$ & $\begin{array}{c}0.304^{* * *} \\
(0.002)\end{array}$ & & & $\begin{array}{c}0.200^{* * *} \\
(0.002)\end{array}$ & $\begin{array}{c}0.250^{* * *} \\
(0.002)\end{array}$ \\
\hline Female & $\begin{array}{c}-0.286^{* * *} \\
(0.001)\end{array}$ & $\begin{array}{c}-0.230^{* * *} \\
(0.002)\end{array}$ & & & $\begin{array}{c}-0.225^{* * *} \\
(0.001)\end{array}$ & $\begin{array}{c}-0.175^{* * *} \\
(0.001)\end{array}$ \\
\hline Organizational level 1 & & & $\begin{array}{c}0.933^{* * *} \\
(0.003)\end{array}$ & $\begin{array}{c}0.751^{* * *} \\
(0.003)\end{array}$ & $\begin{array}{c}0.457^{* * *} \\
(0.003)\end{array}$ & $\begin{array}{c}0.493^{* * *} \\
(0.003)\end{array}$ \\
\hline Organizational level 2 & & & $\begin{array}{c}0.836^{* * *} \\
(0.003)\end{array}$ & $\begin{array}{c}0.709^{* * *} \\
(0.003)\end{array}$ & $\begin{array}{c}0.400^{* * *} \\
(0.003)\end{array}$ & $\begin{array}{c}0.465^{* * *} \\
(0.003)\end{array}$ \\
\hline Organizational level 3 & & & $\begin{array}{c}0.618^{* * *} \\
(0.003)\end{array}$ & $\begin{array}{c}0.477^{* * * *} \\
(0.003)\end{array}$ & $\begin{array}{c}0.266^{* * *} \\
(0.002)\end{array}$ & $\begin{array}{c}0.307^{* * *} \\
(0.003)\end{array}$ \\
\hline Organizational level 4 & & & $\begin{array}{c}0.411^{* * *} \\
(0.002)\end{array}$ & $\begin{array}{c}0.355^{* * * *} \\
(0.003)\end{array}$ & $\begin{array}{c}0.148^{* * *} \\
(0.002)\end{array}$ & $\begin{array}{c}0.219^{* * * *} \\
(0.002)\end{array}$ \\
\hline Organizational level 5 & & & $\begin{array}{c}0.228^{* * *} \\
(0.002)\end{array}$ & $\begin{array}{c}0.211^{* * * *} \\
(0.002)\end{array}$ & $\begin{array}{c}0.088^{* * *} \\
(0.002)\end{array}$ & $\begin{array}{c}0.131^{* * *} \\
(0.002)\end{array}$ \\
\hline Job titles & NO & NO & NO & NO & NO & NO \\
\hline Observations & 632,694 & 712,332 & 632,694 & 712,332 & 632,694 & 712,332 \\
\hline R-squared & 0.646 & 0.469 & 0.528 & 0.435 & 0.719 & 0.574 \\
\hline
\end{tabular}

Notes: ${ }^{1)}$ Cluster robust standard errors, ${ }^{* *} p<0.01,{ }^{* *} p<0.05,{ }^{*} p<0.1{ }^{2)}$ Human capital model incudes also field of education dummies (eight categories). All models contain firm size dummies (six categories), industry dummies (63 categories), and year dummies.

Finally, the parameter estimates for organizational levels increase roughly linearly as we move upwards in the hierarchy. This supports our earlier conclusion about the convex relationship between levels and wages. We also estimated a fixed effects model for hierarchical levels to check whether the convexity result is robust to unobserved individual heterogeneity. ${ }^{16}$ The fixed effects estimates confirm the conclusions based on the OLS estimates.

Another way to examine the importance of hierarchical levels as determinants of wages is to investigate wage changes with movements between levels. In the case that wages are strongly attached to hierarchical levels, we should observe significant wage changes with mobility between levels. Many of the earlier studies on the wage effects of changes in the hierarchical po-

Also the fixed effects estimates are available from the authors upon request. 
sition have focused on promotions inside firms (e.g. McCue 1996, Seltzer and Merrett 2000). We, however, consider several different career moves. To be more specific, we account for the following set of mobility events: i) promotion inside the firm, ii) employer change with promotion, iii) demotion inside the firm, iv) employer change with demotion, v) employer change without a change in the hierarchical level, and vi) same employer and same hierarchical level (omitted group). The other control variables used in the wage regressions are those used in Table 9. Finally, besides a pooled model, we also estimate the model by previous hierarchical level to allow the wage effects of career moves to depend on one's current position in the hierarchy.

Table 10 shows the fixed effects estimates for different career moves. ${ }^{17}$ In line with the earlier literature, we find considerable wage returns to promotions. Promotions inside the firm increase wages, on average, by $4 \%$; promotions with an employer change, roughly 1.8 percentage points more. Although promotions are an important source of wage growth, our estimates of the returns to promotion are, however, somewhat lower than those reported by Baker et al. (1994) and Treble et al. (2001). Baker et al. find that promotions increase wages, on average, by $6 \%$, while in the data used by Treble et al. promotions boost wages as much as $12 \%$. On the other hand, our results about the wage effects of demotions inside the firm are close to those presented by Treble et al., who find that within-firm demotions decrease wages, on average, by $2.6 \%$.

The results by previous hierarchical level indicate that there is indeed a lot of variation in the wage premiums on career moves between levels. Similar to Baker et al., we find the returns to promotion increase with level, especially for internal promotions. Further, the wage effects of demotions differ between levels. Demotions inside firms are especially bad news at the top of the hierarchy, whereas the penalties of demotions with employer changes are highest at level 5. Finally, our results show that there is also a small wage gain associated with lateral employer changes at all levels expect for level 6.

\begin{tabular}{|c|c|c|c|c|c|c|c|}
\hline \multicolumn{8}{|c|}{ Return to career moves, fixed effects estimates } \\
\hline \multicolumn{8}{|c|}{ Salary premiums by type of transition, and accross levels: fixed effects } \\
\hline & All & Prev. Level 1 & Prev. Level 2 & Prev. Level 3 & Prev. Level 4 & Prev. Level 5 & Prev. Level 6 \\
\hline Promotion in current firm & $\begin{array}{c}0.052^{* * * *} \\
(0.000)\end{array}$ & & $\begin{array}{c}0.069^{* * * *} \\
(0.002)\end{array}$ & $\begin{array}{c}0.059^{* * * *} \\
(0.001)\end{array}$ & $\begin{array}{c}0.054^{* * *} \\
(0.001)\end{array}$ & $\begin{array}{c}0.046^{* * * *} \\
(0.001)\end{array}$ & $\begin{array}{c}0.029^{* * * *} \\
(0.002)\end{array}$ \\
\hline Promotion in new firm & $\begin{array}{c}0.074^{* * *} \\
(0.001)\end{array}$ & & $\begin{array}{c}0.089^{* * *} \\
(0.006)\end{array}$ & $\begin{array}{c}0.099^{* * * *} \\
(0.003)\end{array}$ & $\begin{array}{c}0.087^{* * *} \\
(0.003)\end{array}$ & $\begin{array}{c}0.077^{* * * *} \\
(0.002)\end{array}$ & $\begin{array}{c}0.052^{* * * *} \\
(0.006)\end{array}$ \\
\hline Demotion in current firm & $\begin{array}{c}-0.039^{* * *} \\
(0.001)\end{array}$ & $\begin{array}{c}-0.024^{* * *} \\
(0.002)\end{array}$ & $\begin{array}{c}-0.027^{* * *} \\
(0.002)\end{array}$ & $\begin{array}{c}-0.014^{* * *} \\
(0.001)\end{array}$ & $\begin{array}{c}-0.013^{* * *} \\
(0.001)\end{array}$ & $\begin{array}{c}-0.018^{* * *} \\
(0.002)\end{array}$ & \\
\hline Demotion in new firm & $\begin{array}{c}-0.030^{* * *} \\
(0.001)\end{array}$ & $\begin{array}{l}-0.007 \\
(0.005)\end{array}$ & $\begin{array}{c}0.000 \\
(0.003)\end{array}$ & $\begin{array}{c}0.016^{* * *} \\
(0.003)\end{array}$ & $\begin{array}{c}0.011^{* * *} \\
(0.004)\end{array}$ & $\begin{array}{c}-0.033^{* * * *} \\
(0.006)\end{array}$ & \\
\hline Same level in new firm & $\begin{array}{c}0.017^{* * *} \\
(0.000)\end{array}$ & $\begin{array}{c}0.008^{* * *} \\
(0.002)\end{array}$ & $\begin{array}{c}0.015^{* * *} \\
(0.001)\end{array}$ & $\begin{array}{c}0.014^{* * *} \\
(0.001)\end{array}$ & $\begin{array}{c}0.010^{* * *} \\
(0.001)\end{array}$ & $\begin{array}{c}0.008^{* * * *} \\
(0.001)\end{array}$ & $\begin{array}{c}0.006^{* * *} \\
(0.002)\end{array}$ \\
\hline Observations & $2,709,113$ & 177,478 & 322,253 & 489,956 & 673,030 & 953,030 & 93,366 \\
\hline R-squared & & 0.555 & 0.631 & 0.655 & 0.630 & 0.698 & 0.747 \\
\hline
\end{tabular}

Notes: ${ }^{1)}$ Cluster robust standard errors, ${ }^{* * *} p<0.01,{ }^{* *} p<0.05,{ }^{*} p<0.1^{2)}$ Human capital model incudes also field of education dummies (eight categories). All models contain firm size dummies (six categories), industry dummies (63 categories), and year dummies.

Table 10 accounts for both person and firm fixed effects. 


\section{$7 \quad$ Conclusions}

We have examined careers of white-collar workers employed in Finnish manufacturing, following the analysis of Baker et al. (1994) quite closely. Our study adds to their paper in two important ways. First, we use a large linked employer-employee dataset including over 5,000 firms instead of personnel records from a single firm. We thus provide insight into how well the findings of Baker et al. generalize to a larger set of firms. Second, our analysis of career and wage dynamics extends beyond firm boundaries to also cover career moves with employer changes. This is made possible by our unique data that allow us to construct job hierarchies that are comparable across firms.

Similar to Baker et al., we do not find strong support for the existence of ports of entry. Although the share of internal hires increases as we move up the hierarchy, outside hiring plays an important role at all hierarchical levels. Also in line with Baker et al., there is even weaker evidence for the ports of exit. When it comes to career development after the entry into a level, some of our results support the findings of Baker et al., while some do not. In contrast to Baker et al., we do not find that outside hires initially do better in the promotion process than incumbents. Quite the contrary, incumbents seem to be promoted more quickly than external hires during the first years after entry into a level. However, incumbents are also demoted more often. Our finding that incumbents have more variable careers after entrance to a given level is at odds with the findings of Baker et al. However, in our data, external hires have more labor market experience, which may explain our result. Perhaps, the smaller variability among external hires is due to the smaller uncertainty about their abilities. If learning is symmetric, as it is in the Gibbons and Waldman model, then longer labor market experience leads to a more precise estimate of ability. With respect to exits from levels, our results resemble those of Baker et al.: also in our data, exit rates are higher for outside hires than for incumbents during the first years after entry.

Further supporting the findings of Baker et al., we find evidence of fast-tracks and fast-track exits. Furthermore, we find, like Baker et al., that there is tendency for the promoted individuals to be at the upper end of the wage distribution before promotion and at the lower end of the distribution after promotion. This result also holds for promotions to other firms. When the analysis is repeated for exits from the levels, Baker et al. fail to find any consistent pattern. In our data, however, exits rates are higher at the top of the wage distribution than at the bottom.

We extended Baker et al.'s analysis of promotion dynamics by estimating linear promotion models for internal and external promotions. The main conclusions from this analysis are as follows: we observe a positive correlation between years of education and the likelihood of promotion. In line with the fast-track hypothesis, we find that promotion probability decreases with the time spent at the current and previous hierarchical levels. However, controlling for employer fixed effects reverses this result. This is consistent with the Gibbons and Waldman model. We also find that individuals higher in the wage distribution at their current hierarchical level are more likely to be promoted than workers who are at the lower deciles in the wage distribution. The characteristics of the co-workers seem to matter as well. An individual has better chances for promotion if his co-workers are less educated with little tenure. This implies that promotions are not only based on some standards but also that employees compete for promotions. Our results thus suggest that future theoretical work should incorporate these 
aspects of competition to, e.g., the Gibbons and Waldman framework. Interestingly, many of the effects of the different background characteristics on the promotion probability are quite similar for both internal and external promotions.

We ended our analysis of careers by taking a look at wage determination and the role of hierarchical levels in that respect. Similar to Baker et al. (1994), we observe a convex relationship between wages and hierarchical level. There is also substantial wage overlap between hierarchical levels, again in line with Baker et al. This variation of wages within levels indicates that levels do not solely determine wages. A more detailed analysis of the relative importance of hierarchical levels versus human capital in accounting for variation in wages shows that, unlike in Baker et al., human capital explains more of the variance in wages than hierarchical levels. However, this does not mean that levels are unimportant as determinants of wages in our data. For example, during the period of 2001-2005, hierarchical levels accounted for $43.5 \%$ of the variation in wages, which is only 3.4 percentage points lower than the corresponding figure for human capital variables. The importance of hierarchical levels can also be seen from the estimation results examining the wage premiums on different career moves. We find significant positive returns to promotions, whereas demotions result in wage losses. This implies that hierarchical levels indeed play an important role in wage determination.

Overall, our findings are quite consistent with those of previous studies on careers based on case studies using data from a single firm. Given that the models of Gibbons and Waldman $(1999,2006)$ were designed to fit the results in Baker et al. and other studies, it is not surprising that many of our results are consistent with these models. However, not all of the earlier results about the characteristics of internal labor markets are confirmed in our study, suggesting that more research using different data sets from different types of labor markets are clearly needed. Moreover, our results show that for many individuals, moving between employers is an important way to ascend the hierarchical ladder. These results support the recent interest in combining employee turnover and career dynamics within firms in theoretical models. 


\section{References}

Acosta, P. (2010), "Promotion dynamics the peter principle: Incumbents vs. External hires", Labour Economics: forthcoming.

Angrist, J.D. and Pischke, J.-S. (2009), Mostly harmless econometrics: An empiricist's companion, Princeton University Press,Princeton, NJ.

Baker, G., Gibbs, M. and Holmstrom, B. (1994), "The internal economics of the firm: Evidence from personnel data", Quarterly Journal of Economics 109: 881-919.

Baker, G. and Holmstrom, B. (1995), "Internal labor markets: Too many theories, too few facts", American Economic Review 85: 255-259.

Becker, G. (1962), "Investment in human capital: A theoretical analysis", Journal of Political Economy 70: 9-49.

Belzil, C. and Bognanno, M. (2008), "Promotions, demotions, halo effects, and the earnings dynamics of american executives", Journal of Labor Economics 26: 287-310.

Bernhardt, D. (1995), "Strategic promotion and compensation", Review of Economic Studies 62: 315-339.

Blau, F.D. and Devaro, J. (2007), "New evidence on gender differences in promotion rates: An empirical analysis of a sample of new hires", Industrial Relations 46: 511-550.

Booth, A.L. and Francesconi, M. (2000), "Job mobility in 1990s britain: Does gender matter?" In Polachek, S.W. (Ed.), Research in labor economics, vol. 19.: Worker well-being, Elsevier Science, JAI, New York 173-189.

Booth, A.L., Francesconi, M. and Garcia-Serrano, C. (1999), "Job tenure and job mobility in britain", Industrial and Labor Relations Review 53: 43-70.

Chan, W. (1996), "External recruitment versus internal promotion”, Journal of Labor Economics 14: 555.

da Silva, A.D. and van der Klaauw, B. (2005), "Wage dynamics and promotions inside and between firms", Tinbergen Institute, Tinbergen Institute Discussion Papers: 06-084/3.

DeVaro, J. (2006), "Internal promotion competitions in firms", RAND Journal of Economics 37: 521-542.

Dohmen, T.J., Kriechel, B. and Pfann, G.A. (2004), “Monkey bars and ladders: The importance of lateral and vertical job mobility in internal labor market careers", Journal of Population Economics 17: 193-228.

Farber, H.S. (1994), "The analysis of interfirm worker mobility”, Journal of Labor Economics 12: 554-593.

Francesconi, M. (2001), "Determinants and consequences of promotions in britain”, Oxford Bulletin of Economics and Statistics 63: 279-310.

Ghosh, S. (2007), "Job mobility and careers in firms", Labour Economics 14: 603-621.

Gibbons, R. and Waldman, M. (1999), "A theory of wage and promotion dynamics inside firms", Quarterly Journal of Economics 114: 1321-1358.

Gibbons, R. and Waldman, M. (2006), "Enriching a theory of wage and promotion dynamics inside firms", Journal of Labor Economics 24: 59-107.

Jovanovic, B. (1979a), "Firm-specific capital and turnover", Journal of Political Economy 87: 1246-1260. 
Jovanovic, B. (1979b), "Job matching and the theory of turnover", Journal of Political Economy 87: 972 990.

Lazear, E.P. (1992), "The job as a concept", In William J. Bruns, J. (Ed.), Performance measurement, evaluation, and incentives, Harvard Business School Press, Boston: 183-215.

Lazear, E.P. and Oyer, P. (2004), "Internal and external labor markets: A personnel economics approach", Labour Economics 11: 527-554.

Lazear, E.P. and Rosen, S. (1981), "Rank-order tournaments as optimum labor contracts", Journal of Political Economy 89: 841-864.

Le Grand, C. and Tåhlin, M. (2002), "Job mobility within and between jobs", European Sociological Review 18: $142-151$

McCue, K. (1996), "Promotions and wage growth", Journal of Labor Economics 14: 175-209.

Munasinghe, L. and Sigman, K. (2004), "A hobo syndrome? Mobility, wages, and job turnover", Labour Economics 11: 191-218.

Neal, D. (1999), "The complexity of job mobility among young men", Journal of Labor Economics 17: 237261.

Parrado, E., Caner, A. and Wolff, E.N. (2007), "Occupational and industrial mobility in the united states", Labour Economics 14: 435-455.

Pavlopoulos, D., Fouarge, D., Muffels, R. and Vermunt, J.K. (2007), "Job mobility and wage mobility of high- and low-paid workers", Schmollers Jahrbuch: Zeitschrift fur Wirtschafts- und Sozialwissenschaften/ Journal of Applied Social Science Studies 127: 47-58.

Pergamit, M.R. and Veum, J.R. (1999), "What is a promotion?" Industrial and Labor Relations Review 52: $581-601$.

Ransom, M. and Oaxaca, R.L. (2005), "Intrafirm mobility and sex differences in pay", Industrial and Labor Relations Review 58: 219-237.

Rosen, S. (1986), "Prizes and incentives in elimination tournaments", American Economic Review 76: $701-$ 715.

Seltzer, A. and Merrett, D.T. (2000), "Personnel policies at the union bank of australia: Evidence from the 1888-1900 entry cohorts", Journal of Labor Economics 18: 573-613.

Sicherman, N. and Galor, O. (1990), "A theory of career mobility", Journal of Political Economy 98: 169-192.

Topel, R.H. and Ward, M.P. (1992), "Job mobility and the careers of young men", Quarterly Journal of Economics 107: 439-479.

Treble, J., van Gameren, E., Bridges, S. and Barmby, T. (2001), "The internal economics of the firm: Further evidence from personnel data", Labour Economics 8: 531-552.

Waldman, M. (1984), "Job assignments, signalling, and efficiency", RAND Journal of Economics 15: 255-267.

Waldman, M. (2007), "Theory and evidence in internal labor markets", MPRA Paper No. 5113. 



\section{Aikaisemmin ilmestynyt ETLAn Keskusteluaiheita-sarjassa Previously published in the ETLA Discussion Papers Series}

No 1229 Markku Kotilainen - Nuutti Nikula, Why do Firms Invest in the Baltic Sea Region? 19.11.2010.36 p.

No 1230 Rita Asplund - Reija Lilja, Wage Formation and Gender Wage Gaps: The Changing Role of Human Capital in the Finnish Technology Industry. 03.12.2010. 22 p.

No 1231 Tuomo Nikulainen - Hannele Salminen - Pekka Ylä-Anttila, Ammattikorkeakoulujen asema ja uudistuminen - Taustakyselyn tuloksia. 01.12.2010. $28 \mathrm{~s}$.

No 1232 Ilkka Ylhäinen, Persistence of Government Funding in Small Business Finance. 13.12.2010. 33 p.

No 1233 Antti-Jussi Tahvanainen - Tuomo Nikulainen, Tutkimusympäristö muutoksessa - Tutkijoiden näkemykset SHOK:n, korkeakoulukeksintölain ja yliopistolain vaikutuksista. 22.12.2010. $18 \mathrm{~s}$.

No 1234 Antti-Jussi Tahvanainen - Tuomo Nikulainen, Commercialiazation at Finnish Universities - Researchers' Perspectives on the Motives and Challenges of Turning Science into Business. 10.01.2011. 47 p.

No 1235 Heli Koski-Mika Pajarinen, Do Business Subsidies Facilitate Employment Growth? 04.01.2011. 20 p.

No 1236 Antti-Jussi Tahvanainen - Raine Hermans, Making Sense of the TTO Production Function: University Technology Transfer Offices as Process Catalysts, Knowledge Converters and Impact Amplifiers. 11.01.2011. $40 \mathrm{p}$.

No 1237 Jukka Lassila - Tarmo Valkonen, Julkisen talouden rahoituksellinen kestävyys Suomessa. 11.01.2011. 28 s.

No 1238 Martin Kenney - Bryan Pon, Structuring the Smartphone Industry: Is the Mobile Internet OS Platform the Key. 10.02.2011.24 p.

No 1239 Mika Maliranta-Reijo Mankinen - Paavo Suni-Pekka Ylä-Anttila, Suhdanne- ja rakennekriisi yhtä aikaa? Toimiala- ja yritysrakenteen muutokset taantumassa. 17.02.2011. $20 \mathrm{s.}$

No 1240 Jyrki Ali-Yrkkö - Petri Rouvinen - Timo Seppälä-Pekka Ylä-Anttila, Who Captures Value in Global Supply Chains? Case Nokia N95 Smartphone. 28.02.2011. 22 p.

No 1241 Antti Kauhanen - Sami Napari, Gender Differences in Careers. 9.03.2011. 31 p.

No 1242 Mika Pajarinen - Petri Rouvinen - Pekka Ylä-Anttila, Omistajuuden vaikutus suomalaisen työllisyyden kasvuun ja pysyvyyteen. 16.03.2011. $27 \mathrm{~s}$.

No 1243 Rita Asplund - Sami Napari, Intangibles and the Gender Wage Gap. An Analysis of Gender Wage Gaps Across Occupations in the Finnish Private Sector. 22.03.2011. 24 p.

Elinkeinoelämän Tutkimuslaitoksen julkaisemat "Keskusteluaiheita" ovat raportteja alustavista tutkimustuloksista ja väliraportteja tekeillä olevista tutkimuksista. Tässä sarjassa julkaistuja monisteita on mahdollista ostaa Taloustieto Oy:stä kopiointi- ja toimituskuluja vastaavaan hintaan.

Papers in this series are reports on preliminary research results and on studies in progress. They are sold by Taloustieto Oy for a nominal fee covering copying and postage costs.

Julkaisut ovat ladattavissa pdf-muodossa osoitteessa: www.etla.fi/julkaisuhaku.php

Publications in pdf can be downloaded at www.etla.fi/eng/julkaisuhaku.php

\section{ETLA}

